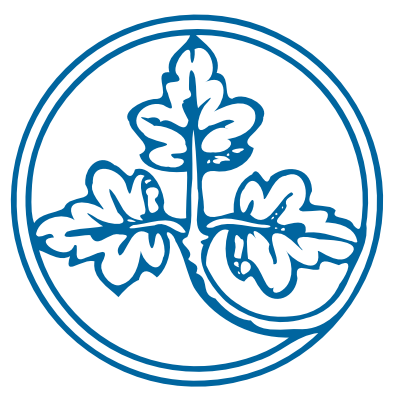

Are economic preferences shaped by the family context? The impact of birth order and siblings' sex composition on economic preferences

Lena Detlefsen Andreas Friedl Katharina Lima de Miranda Ulrich Schmidt Matthias Sutter

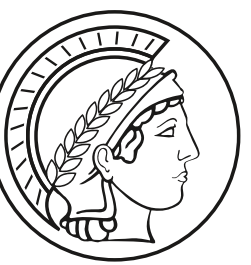




\section{Are economic preferences shaped by the family context? The impact of birth order and siblings' sex composition on economic preferences}

Lena Detlefsen / Andreas Friedl / Katharina Lima de Miranda / Ulrich Schmidt/ Matthias Sutter

November 2018 


\title{
Are economic preferences shaped by the family context? The impact of birth order and siblings' sex composition on economic preferences
}

\author{
Lena Detlefsen, Andreas Friedl, Katharina Lima de Miranda, \\ Ulrich Schmidt and Matthias Sutter*
}

\begin{abstract}
The formation of economic preferences in childhood and adolescence has long-term consequences for life-time outcomes. We study in an experiment with 525 teenagers how both birth order and siblings' sex composition affect risk, time and social preferences. We find that second born children are typically less patient, less risk averse, and more trusting. However, siblings' sex composition interacts importantly with birth order effects. Second born children are more risk taking only with same-sex siblings. For trust and trustworthiness, birth order effects are larger with mixed-sex siblings than in the single-sex case. Only for patience, siblings' sex composition does not matter.
\end{abstract}

JEL classification: C93, D10, D90, J12

Keywords: Birth order, siblings' sex composition, economic preferences, experiment

This version: 9 November 2018

\footnotetext{
* Detlefsen, University of Kiel and Kiel Institute for the World Economy, Kiellinie 66, DE-24105 Kiel, Germany (Lena.Detlefsen@ifw-kiel.de). Friedl: Friedrich-Alexander University Erlangen-Nürnberg, Lange Gasse 20, DE-90403 Nürnberg, (andreas.friedl@fau.de). Lima de Miranda: Kiel Institute for the World Economy, Kiellinie 66, DE-24105 Kiel, Germany (Katharina.Miranda@ifw-kiel.de). Schmidt: University of Kiel, University of Johannesburg and Kiel Institute for the World Economy, Kiellinie 66, DE-24105 Kiel, Germany (Ulrich.Schmidt@ifw-kiel.de). Sutter: Max Planck Institute for Research on Collective Goods Bonn, and University of Cologne, Germany, and University of Innsbruck, Austria (matthias.sutter@coll.mpg.de). We would like to thank in particular the principals of the participating schools for making this study possible. We have received very helpful comments from Bertil Tungodden, Kjell Salvanes, Alexander Cappelen, Ingvild Almas and audiences at SMYE in Lisboa, IMEBESS in Rome, ESA in Berlin, Nordic Conference on Behavioural and Experimental Economics in Gothenburg, ESPE in Berlin, SPUDM in Budapest, SBRCR in Kiel, the Choice Lab seminar in Bergen, Research Workshop and Summer School in Economics of Education and Self-regulation in Mainz and the seminar at the Kiel Institute for World Economy. Financial support from the Kiel Institute for World Economy is gratefully acknowledged.
} 


\section{Introduction}

Economic preferences shape the outcomes of one's life to a large extent. For instance, time preferences are related to school performance and thus educational achievements, meaning that they affect labor market outcomes and lifetime income (Heckman et al., 2006; Castillo et al., 2011; Moffitt et al., 2011; Golsteyn et al., 2014; Alan and Ertac, 2018). Risk preferences have an influence on financial behavior (Meier and Sprenger, 2010, 2013), and social preferences, like trust and reciprocity, are important for cooperation within a society and can even help markets work efficiently (Fehr et al., 1993; Knack and Keefer, 1997; Zak and Knack, 2001; Kerschbamer et al., 2017).

Only in more recent years, economists have become very much interested in the formation of economic preferences. Promoting a better understanding of the development of economic preferences promises to provide insights into the sources of heterogeneity in economic preferences among subjects, and therefore also reveals potential anchor points for policy interventions to mold economic preferences. While some studies show that the variation in economic preferences can at least partly be explained by genetic variation (Cesarini et al., 2009; Zyphur et al., 2009), large parts of differences in economic preferences still require additional explanations that are related to different environments in which subjects grow up and make economic choices. Besides looking at the influence of schools and peer groups, the influence of families has naturally captured lots of attention in this literature about the formation of economic preferences. For instance, several studies have addressed the influence of the socio-economic status of parents on children's economic preferences, typically finding that higher socio-economic status of parents goes along with more patient children who are also more risk tolerant, more often prosocial and more competitive (Dohmen et al., 2012; Kosse and Pfeiffer, 2012; Bauer et al., 2014; Almas et al., 2016; Deckers et al., 2017). Besides acknowledging the influence of parents, it is straightforward to realize that siblings may also have an impact on each other.

In fact, there is an influential literature showing that birth order affects outcomes. For example, later born children have lower IQ (Bjerkedal et al., 2007; Black et al., 2011), lower education (Black et al., 2005; Booth and Kee, 2008; Härkönen, 2014), higher mortality risks (Barclay and Kolk, 2015; Modin, 2002), they earn less (Behrman and Taubman, 1986; Björklund and Jäntti, 2012) and are more likely to smoke (Black et al., 2016). The development of cognitive skills is substantially influenced by older siblings (Dai and Heckman, 2013). Interestingly, there is much less evidence on how birth order affects economic preferences, although the latter have an impact on economic outcomes. Moreover, the related literature - discussed below in more detail - typically focuses on birth order effects and puts little (or no) emphasis on siblings' sex composition (that refers to whether siblings have the same sex or are of different sex). 
Siblings - and thus birth order and the sex composition of siblings - can be expected to have an impact on economic preferences because siblings compete for parental attention. As a consequence, children adapt their behavior to reach this goal, which may lead to differentiate one's behavior from siblings' behavior to capture more parental attention (Sulloway, 1996; Hertwig et al., 2002). Yet, besides this tendency to show different behavior than one's siblings, siblings may also have the opposite effect of assimilating behavior, because siblings can learn from each other through imitation (Rust et al., 2000). Given that birth order and sibling's sex composition are important for parental behavior and sibling's interaction and potential imitation or differentiation (Whiteman et al., 2007), we are going to study how birth order and siblings' sex composition are related to three key domains of economic preferences, namely time, risk and trust preferences. A major contribution of this study is to disentangle the birth order and the siblings' sex composition effect on economic preferences, and check whether these effects also interact with a subject's sex.

We present an experimental study with 525 adolescents in $10^{\text {th }}$ grade and an average age of 16 years. The experiment was run during regular school hours, thus minimizing drop-outs and selfselection issues. The experimental elicitation of time, risk, and trust preferences was incentivized, and questionnaire data allows us to relate experimental choices to the family context, in particular to both birth order and siblings' sex composition.

We focus in our study on adolescents and do this for several reasons. First, this age is of immense practical importance and of scientific interest, as it is right at the border between having to accept the decision of one's parents and making one's own (significantly influential) life decisions for the first time. Second, adolescence is a phase in life which sets the cornerstone for lifetime outcomes such as educational choices, or the creation of habits which are known to be hard to change once acquired (like smoking, drinking or unhealthy diet). ${ }^{1}$ Third, adolescents are still integrated into their family context and, therefore, family composition should not be diluted by later developments in life after leaving the parents' house. Fourth, work on siblings' role in gender development suggests that the differentiation of siblings (in relation to other siblings) sets in during adolescence as youths focus on developing their unique identities (Grotevant, 1978; McHale et al., 2001).

The broad set of economic preferences investigated, and the opportunity to speak to both the importance of birth order and siblings' sex composition and to identify the relative effect of both factors sets our paper apart from previous studies. In general, the research in economics regarding birth order, siblings' sex composition and economic preferences is still scarce. Some important studies focus on risk preferences - one of the three types of economic preferences we are looking at

\footnotetext{
${ }^{1}$ For example smoking during adolescence, even infrequently, is a highly significant predictor of later regular smoking, up to the point that those who did not smoke during adolescence will most likely never start smoking (Chassin et al., 1990).
} 
- and the influence of the family context. Dohmen et al. (2012) show that first born children are more similar to their parents in terms of risk preferences than later born ones and Alan et al. (2017) report that the correlation between mother's and daughter's risk preferences is very strong and significant, while it is much weaker and insignificant for mothers and boys. Consistent with this view, later born children have been found to be less risk averse than first borns using field behavior data (Yiannakis, 1976; Sulloway and Zweigenhaft, 2010). Using a large Swedish survey sample of adults, Lampi and Nordblom (2011) relate both time and risk preferences to birth order, finding that later born children are less patient than first born children. Three features distinguish their work from ours. Their survey did not involve incentives, they had adult participants, and they did not investigate trust. The only studies we know that focus on birth order effects and use incentivized experiments are the studies by Courtiol et al. (2009) and Okudaira et al. (2015). Courtiol et al. (2009) found in a sample of French students that first born children are less trustful and reciprocate less than later born children in a standard investment game by Berg et al. (1995). They used an incentivized experiment, but in comparison to our paper they did not relate their findings to siblings' sex composition, nor did they study risk or time preferences. Furthermore, while we studied adolescents for the reasons explained above, Courtiol et al. (2009) let adult university students participate in their study. Okudaira et al. (2015) examined competitive behavior and reported no birth order effects. Yet, they found that the siblings' sex composition matters; men with older sisters were less competitive than men with older brothers in their Japanese high school sample. So, they considered both birth order and siblings' sex composition, as we do, but we consider a different and larger set of economic preferences by focusing on risk, time, and trust preferences.

We find that birth order is an important factor for all three preferences and, moreover, that for trust and risk preferences, the siblings' sex composition has a significant impact as well. First born children are in general more patient and trust less than second born children. However, while patience is independent of the siblings' sex composition, trust increases for boys in mixed sex families. Additionally, second born children are only more risk taking when all siblings have the same sex. In case of mixed sex siblings, children vary in their risk preferences with regard to the gender. Boys are more risk taking than girls, but there is no birth order effect, implying that the gender effect dominates any potential birth order effect. Most of these results are in line with our hypotheses that we are going to present in the following section II. Afterwards, we introduce in section III the experimental design of our study. Section IV presents our results in detail. Section V discusses the results and relates them in particular to our hypotheses, and section VI concludes the paper. 


\section{Hypotheses}

Birth order position and siblings' sex composition may affect economic preferences for two reasons. First, parental investment differs among siblings. First born children usually have access to more family resources than later born ones (Sulloway, 1996). For example it has been shown that first born children spend more quality time with their parents than second born children, even when parents try to divide their time equally between their offspring (Hertwig et al., 2002; Price, 2008). They also benefit from an early absence of sibling rivals for a share of parental investment (Jacobs and Moss, 1976). ${ }^{2}$ Not only birth order has an impact on parental treatment, also the siblings' sex composition is important. In general it has been found that parents favor the child of their own sex such that mothers spend the least time with their children if they have only boys (Crouter et al., 1995; McHale et al., 2000). This differentiated parental treatment is especially apparent in mixed-sex dyads of siblings, where mothers and fathers tend to spend relatively more time with the child of their own sex and their treatment tends to differ more between boys and girls. Gender specific treatment can lead to an enforcement of gender socialization and gender stereotypical behavior of children, which is more pronounced in mixed-sex dyads. It has been shown for example that boys who spend more time with their fathers comply more with gender stereotypes (Lawson et al., 2015) and that girls with brothers do on average more housework (Crouter et al., 1999; McHale et al., 1999, 2000)

Second, in addition to differentiated parental investment, the presence of siblings as such plays an important role in child development. Children react to siblings and do this in two different ways (e.g. Whiteman et al., 2007). First, children compete as afore-mentioned over parental attention. To reduce direct competition and to get a share of parental time children try to find their own niche to make it difficult for parents to compare them. This attempt to differentiate oneself from other siblings is known as de-identification (Sulloway, 1996). The de-identification process can depend on the birth order (Sulloway, 1996) and is in general more pronounced if siblings have different sex (Feinberg et al., 2003). The second mechanism is social learning. Children learn from their siblings and copy their behavior, making for example girls with brothers more masculine and boys with sisters more feminine (Rust et al., 2000). This process can be especially important for younger siblings due to the tendency of imitating higher status models (Rust et al., 2000) and for same sex dyads due to higher intimacy (e.g., Hetherington, 1991; Buhrmester, 1992; Tucker et al., 1997). Social learning increases the likelihood that children who have an older sibling of the other sex have less stereotyped gender role concepts (Stoneman et al., 1986; Rust et al., 2000).

\footnotetext{
${ }^{2}$ It has been shown that first born children grow faster (Meredith, 1950; Wingerd, 1970) such that there exists a strong and significant negative correlation between birth order and height (Hatton and Martin, 2010; Lundborg et al., 2014).
} 
From the above considerations we can derive the following hypotheses for our three domains of economic preferences.

\section{A. Time preferences}

First born children tend to spend more quality time with their parents (Price, 2008) and to conform more with parental values than their younger siblings (Sulloway, 1995, 1996). In the case of time preferences this would lead to first born children being more patient than their younger siblings given that adults have been found to be in general more patient than adolescents (Lahav et al, 2010). The reaction of second born children would be to be less patient if they followed the aspect of deidentification or to be also patient if social learning dominated de-identification.

Hypothesis 1: a) Second born children are less patient than first born children if de-identification dominates. b) There are no time preference differences between first born children and second born children if social learning dominates.

Time preferences show in general no clear pattern with regard to the gender of the child. ${ }^{3}$ Therefore, parental behavior should not be different in this matter, nor should social learning and deidentification differ between single sex and mixed sex siblings.

Hypothesis 2: The siblings' sex composition has no influence on time preferences.

\section{B. Risk Preferences}

In line with Sulloway (1995;1996), Dohmen et al. (2012) found that first born children are more similar to their parents in terms of risk preferences than later born ones and that the willingness to take risks decreases with age. The size of the differences between first and second born children depends on the siblings' de-identification and social learning.

Hypothesis 3: a) Second born children are less risk averse than first born children if deidentification dominates. b) There are no risk preference differences between first born children and second born children if social learning dominates.

\footnotetext{
${ }^{3}$ For example, Dohmen et al. (2010) and Deckers et al. (2017) found that boys are more patient than girls, while studies by Bettinger and Slonim (2007) and Castillo et al. (2011) found that girls are more patient than boys.
} 
However, as risk preferences have been found to differ between boys and girls (Croson and Gneezy, 2009, Cárdenas et al., 2012; Deckers et al., 2017) and parents have been found to differ in their treatment of girls and boys especially in the encouragement of sex-typed activities (Lytton and Romney, 1991) we presume that the results for de-identification or social learning in families with single sex or mixed sex siblings will be different. First, studies found that the de-identification process is more pronounced with mixed sex siblings compared to single sex siblings (Feinberg et al., 2013), so children might rather try to differ from their siblings by acting in line with the gender stereotype than by differing with respect to birth order. In the case of mixed sex siblings this would imply that girls will tend to be more risk averse and boys more risk seeking, independent of their birth order position. Second, studies show that children copy their siblings (e.g., Koch, 1956; Sutton-Smith and Rosenberg, 1970). Therefore, gender differences should be smaller with mixed sex siblings as boys and girls converge in their behavior under these circumstances.

Hypothesis 4: The siblings' sex composition has an influence on risk preferences, such that birth order has a stronger impact in case of same sex siblings.

\section{Trust and Trustworthiness}

Different from time and risk preferences, social learning is an important mechanism for trust behavior. Children learn from their siblings, especially younger siblings from their older siblings (Rust et al., 2000). Older brothers and sisters are more likely to reciprocate than younger children and thus younger siblings experience more instances of positive reciprocity than do older siblings (Hardin, 2001) and learn by these role models. This is in line with the finding that trust and trustworthiness increase from early childhood to early adulthood and that children trust older children in general more than children of their own age (Sutter and Kocher, 2007).

Hypothesis 5: Second born children trust more than first born children and are more trustworthy than first born children

The social learning process might differ with regard to the gender composition of siblings. While men trust in general more, women reciprocate more (Buchan et al., 2008). So, if boys have sisters they learn that they can trust (their sisters) and be trustworthy, while girls with brothers learn the opposite. This could lead to differences in the trust level between mixed and single sex siblings. 
Hypothesis 6: Gender differences in the levels of trust and trustworthiness are more pronounced in mixed sex siblings. Boys trust more and are more trustworthy if they have sisters. Girls trust less and are less trustworthy if they have brothers.

\section{Experimental Design}

Our study was carried out in 27 classes from eight secondary schools in the German state of Schleswig-Holstein, including 525 students who were all attending $10^{\text {th }}$ grade in school. The schools included three different types of secondary schools that vary in level and length of schooling. ${ }^{4}$ Having different school types offered us the possibility to get students with different socio-economic and intellectual backgrounds. The study was approved by the Ministry of School and Professional Education and the principals and teachers of the participating schools gave permission to conduct the experiments during regular school hours. Parents were informed about the experiment and also gave their permission. Participation of students was, of course, also voluntary, but none opted out.

The experiment was computerized, using the mobile Kiel Econ Lab and z-tree (Fischbacher, 2007). Experimental sessions were conducted with up to 25 participants per session in dedicated class rooms and lasted about 45 minutes. Since the experiments were run during regular school hours we minimized dropouts and self-selection. All students faced the same set of explanations, decision tasks, questionnaires and payoffs. While inside a classroom all students faced the same sequence of decision tasks, it was randomized on the class level in order to account for possible order effects. The experiments were incentivized and each subject was paid according to her or his choices. At the end of the experimental session, one decision was randomly selected for payment. It was explained that the choices were anonymous and that payments would be handed out in sealed envelopes, which one experimenter would prepare and another experimenter would distribute to the participants in a double blind procedure. Payments were on average €4.32. Students were directly paid in $\operatorname{cash}^{5}$, except if

\footnotetext{
${ }^{4}$ The school types are Gymnasium (3 schools), Gemeinschaftsschule (3), and Regionalschule (2). Since 2014, the education act of Schleswig-Holstein (Schleswig-Holsteinisches Schulgesetz) intends a two-tier secondary education system with community schools (Gemeinschaftsschule) and high schools (Gymnasium), which start after 4 years of elementary school. We also have two regional schools (Regionalschule) in our sample, a school type to be discontinued after 2019. The main differences between the different school types are the following. In a community school all educational qualifications of secondary education can be acquired in a common educational framework. This is the first general education qualification ("Erster allgemeinbildender Schulabschluss") after the 9th grade, the "Mittlere Reife" after the 10th grade, which both qualify for vocational training, and in addition the "Abitur" after the 13th grade, qualifying for university admission. High schools prepare students for higher education. In the majority of high schools, students can achieve their "Abitur" after the 12th grade. Regional schools terminate after the 10th school year, thus they can not qualify for university admission. Information from this paragraph is based on the state's website (Landesportal Schleswig-Holstein; 2017).

${ }^{5}$ We were able to pay all children in cash, except for one school. In this school the children could earn coupons for the cafeteria, which was perceived as equivalent to cash because students could spend their coupons on whatever they liked in the canteen, for example lunch or sweets.
} 
future payments became necessary in the time preference task, in which case a sealed envelope was handed to the teacher who was instructed to hand it to the according subject on the determined date in the future. The teachers had no information regarding the task and could therefore draw no conclusion about the behavior of the children.

\section{A. Time Preferences}

Time preferences were elicited through a choice list of 20 binary choices (similar to the lists used in Bettinger and Slonim, 2007, or Sutter et al., 2013, who also worked with children and who reported good understanding of children). In the list presented in Table 1, subjects were asked to choose between a payment today and a payment in three weeks. The early payment remained fixed at $€ 4.00$ and the delayed payment increased monotonically in $€ 0.10$ steps from $€ 4.00$ to $€ 5.90$. To calculate the future equivalent, we take the switching point between the last immediate payment and the first delayed payment. The choice lists were designed in a way that it was not possible to switch more than once from the left to the right hand side in each list, a procedure that has been used in other experiments as well (e.g., Dohmen et al., 2010). In the example in Table 1 the future equivalent would be $4.25 €$. Higher levels of the future equivalent indicate a higher level of impatience.

\section{TABLE 1: EXAMPLE: CHOICE LIST FOR TIME PREFERENCES}

\begin{tabular}{|c|c|c|c|c|c|}
\hline 1) & $€ 4.00$ today & 凶 & or & $€ 4.00$ in 3 weeks & $\square$ \\
\hline 2) & $€ 4.00$ today & 区 & or & $€ 4.10$ in 3 weeks & $\square$ \\
\hline 3) & $€ 4.00$ today & 凶 & or & $€ 4.20$ in 3 weeks & $\square$ \\
\hline 4) & $€ 4.00$ today & $\square$ & or & $€ 4.30$ in 3 weeks & 区 \\
\hline 5) & $€ 4.00$ today & $\square$ & or & $€ 4.40$ in 3 weeks & 区 \\
\hline$\ldots$ & $\ldots$ & & ... & .. & \\
\hline 20) & $€ 4.00$ today & $\square$ & or & $€ 5.90$ in 3 weeks & 区 \\
\hline
\end{tabular}

\section{B. Risk preferences}

We elicited risk preferences by using the design of Eckel and Grossman (2002). This design has been shown to be easy to understand for a broad range of socioeconomic groups with diverse mathematical skills (Dave et al., 2010), making it suitable also for our study with children. The students had to choose one out of the six lotteries that are displayed in Figure 1. In each lottery, the chances to win a high or low prize were equal to $50 \%$. The lotteries increased in risk and expected value, starting from the top of Figure 1 with a sure gain of $€ 4$ and continuing in clockwise order to the two last lotteries with an expected value of $€ 5$. Overall, risk aversion decreased from the first to 
the last lottery. Note that the two last lotteries had the same expected value, but the lottery with prizes $€ 9$ or $€ 1$ was riskier than the penultimate one with prizes of $€ 8$ or $€ 2$.
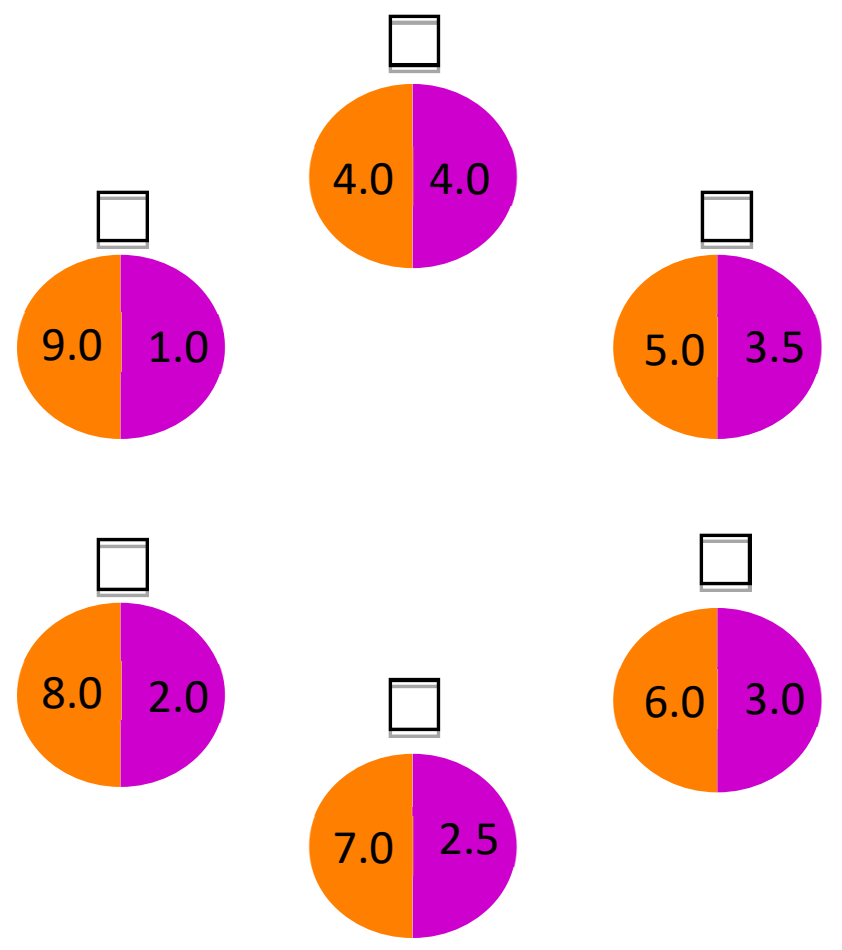

FIGURE 1: RISK PREFERENCE TASK

Notes: The lottery at the top will be coded as Lottery 1, and in clockwise order the following lotteries are coded as lotteries 2-6. Higher lottery numbers imply more risk taking.

\section{Trust and Trustworthiness}

Trust and trustworthiness were elicited with the investment game by Berg, Dickhaut, and McCabe (1995). Both players in this game were endowed with €2 in the beginning. The sender could then transfer an amount between $€ 0$ and $€ 2$ to the receiver. The transfer was tripled and the receiver could return any amount between zero and the tripled transfer to the sender. Participants played in both roles.

\section{Further Variables of Interest}

In addition to the experimental tasks on time, risk and trust preferences, the subjects had to solve ten raven matrices as an indicator for cognitive reflection. At the end of the experiment a questionnaire with demographic questions as well as questions regarding individual field behavior was administered (see the Appendix for all items). Demographic questions included age, gender, height, weight, number of siblings, age of siblings and siblings' sex, as well as information about 
their parents. Furthermore, the socioeconomic background was measured with the family affluence scale (FAS) (Currie et al., 1997), which has been especially developed for children and builds on selfreported information on a subject's household (own room, holidays, number of books, cars and computers). Higher levels thereby indicate a higher socio-economic background (Boyce et al., 2006).

\section{Results}

Table 2 presents an overview of the descriptive statistics and the experimental choices. In our complete sample of 525 students, 50.3 percent are male. The average age is 15.95 years and 40 percent of students attend a Gymnasium, which is close to the German average (of 46 percent). On average, the students have 1.51 siblings (1.16 biological siblings); 12.57 percent of them are only children, 47.81 percent have one sibling and 23.81 percent have two siblings. Of those who have siblings, 34.29 percent are first born, 33.33 percent are second born, 13.52 percent are third born, and 6.28 percent are fourth or later born children.

In the following analysis, we have to exclude those students who are single children. Moreover, we focus our analysis on first born and second born children, since birth order effects are assumed to be largest between the oldest children in families (Schacter et al., 1976, 1978). In order to keep a sufficiently large sample size, we do not only restrict our sample to families with two children only, but also include families with three children (while analyzing only the first and second born). This yields a set of 312 adolescents, whose summary data are shown on the right-hand side of Table 2. Regarding the economic preferences there are no significant differences between the sample of all 525 adolescents and the subsample of 312 adolescents that we use for our analysis. The only (weakly significant) difference between the samples is found in the age of the mothers as the 312 children included in the analysis have in general a younger mother, because we only concentrate on first and second born children. ${ }^{6}$ Of those 312 adolescents, almost exactly 50\% are first born and 50\% are second born, and $67.6 \%$ of them grew up in families with a single sex siblings-composition. When examining the effect of the sex-composition of siblings in the paper, we will consider only the sex of the first born and second born child and classify the composition as either single sex or mixed sex. Since we also include families with three children, our approach presented in the paper ignores the sex of the third child. In Appendix B we show that the main results presented in the paper are robust to a more conservative splitting of the sample with respect to siblings' sex composition where we define single sex as only those cases where all siblings have the same sex also in families with three

\footnotetext{
${ }^{6}$ We only control for the age of the mother, because not in all cases the age of the father was known.
} 
children. Given this robustness, we proceed here with our approach of looking at the sexes of the first born and second born only.

TABLE 2 DESCRIPTIVE STATISTICS

\begin{tabular}{|c|c|c|c|c|c|c|c|c|c|c|c|}
\hline \multirow[b]{2}{*}{ Variable } & \multicolumn{5}{|c|}{ Complete Sample } & \multicolumn{5}{|c|}{$\begin{array}{c}\text { Sub-Sample } \\
\text { (Families with } 2 \text { or } 3 \text { children) }\end{array}$} & \multirow{2}{*}{$\begin{array}{l}\text { Diff. } \\
\text { (Prob } \\
>|z| \text { ) }\end{array}$} \\
\hline & Obs. & Mean & SD & Min & Max & Obs. & Mean & SD & Min & Max & \\
\hline Male & 525 & 0.50 & 0.50 & 0 & 1 & 312 & 0.52 & 0.50 & 0 & 1 & 0.584 \\
\hline Age & 525 & 15.95 & 0.64 & 15 & 18 & 312 & 15.94 & 0.65 & 15 & 18 & 0.859 \\
\hline Gymnasium & 525 & 0.4 & 0.49 & 0 & 1 & 312 & 0.43 & 0.5 & 0 & 1 & 0.402 \\
\hline FAS & 525 & 11.34 & 2.29 & 4 & 16 & 312 & 11.43 & 2.26 & 4 & 16 & 0.500 \\
\hline Raven test & 525 & 7.09 & 1.09 & 0 & 10 & 312 & 7.09 & 1.16 & 0 & 10 & 0.866 \\
\hline Pocket money* & 524 & 37.82 & 36.79 & 0 & 587 & 311 & 36.95 & 40.88 & 0 & 587 & 0.421 \\
\hline Mother's age at birth & 524 & 30.37 & 4.77 & 15 & 48 & 312 & 29.78 & 4.34 & 15 & 41 & 0.090 \\
\hline No. Siblings & 525 & 1.51 & 1.09 & 0 & 5 & 312 & 1.2 & 0.4 & 1 & 2 & 0.000 \\
\hline $\begin{array}{l}\text { Spacing in years } \\
\left(1^{\text {st }} / 2^{\text {nd }}\right)\end{array}$ & 525 & & & & & 312 & 3.28 & 1.99 & 0 & 13 & \\
\hline First born ${ }^{\#}$ & 525 & 0.35 & 0.48 & 0 & 1 & 312 & 0.5 & & 0 & 1 & 0.000 \\
\hline Second born ${ }^{\#}$ & 525 & 0.33 & 0.47 & 0 & 1 & 312 & 0.5 & & 0 & 1 & 0.000 \\
\hline Single sex & 525 & 0.57 & 0.5 & 0 & 1 & 312 & 0.68 & 0.47 & 0 & 1 & 0.003 \\
\hline \multicolumn{12}{|l|}{ Experimental choices } \\
\hline Future equivalent & 525 & 4.90 & 0.62 & 4 & 5.9 & 312 & 4.89 & 0.61 & 4 & 5.9 & 0.692 \\
\hline Risk & 525 & 2.6 & 1.69 & 1 & 6 & 312 & 2.71 & 1.72 & 1 & 6 & 0.380 \\
\hline Trust & 525 & 1.31 & 0.6 & 0 & 2 & 312 & 1.3 & 0.6 & 0 & 2 & 0.764 \\
\hline Trustworthiness & 525 & 0.7 & 0.38 & 0 & 1.69 & 312 & 0.68 & 0.38 & 0 & 1.69 & 0.556 \\
\hline
\end{tabular}

Notes:

* Pocket money is measured in Euro per month.

\# Fraction of children who are first, respectively, second born (conditional on having siblings).

We test differences between the samples by using the Wilcoxon ranksum test.

\section{A. Time preferences}

Table 3 shows the average choices in the time preferences experiment. The numbers in the table indicate the future equivalent, i.e., the amount of money that participants need to get in three weeks in order to give up an immediate payment of $€ 4.00$. On average, this future equivalent is $€ 4.89 €$ (and it is $€ 4.90$ in the complete sample of 525 students). It differs only slightly, and insignificantly, across gender with $€ 4.87$ for boys and $€ 4.91$ for girls (Wilcoxon ranksum test: $z=0.245$, Prob $>|z|=0.8063$ ). 
TABLE 3: TIME PREFERENCES (FUTURE EQUIVALENT, IN $€$ )

\begin{tabular}{lcllll}
\hline \hline & All & \multicolumn{2}{c}{ Boys } & \multicolumn{2}{c}{ Girls } \\
& & Single sex & Mixed sex & Single sex & Mixed sex \\
$1^{\text {st }}$ born & 4.812 & 4.733 & 4.820 & 4.869 & 4.886 \\
$2^{\text {nd }}$ born & 4.957 & 4.932 & 5.083 & 4.944 & 4.910 \\
All (mixed/single) & & 4.833 & 4.951 & 4.907 & 4.898 \\
All & 4.885 & & 4.866 & & 4.905 \\
\hline \hline
\end{tabular}

The average future equivalent for first born children is $€ 4.812$ and for second born children $€ 4.957$. This difference is significant at the 5\%-level $(z=-2.025$, Prob $>|z|=0.0428)$.

Table 4 presents a Tobit regression that includes several background variables. In Model 1 it confirms that there is no gender difference in patience. Model 2 shows, however, a strong birth order effect, such that second-born children are significantly more impatient than first-born children, which is consistent with our Hypothesis 1 a).

As we do not have a gender effect in our data, the question remains if we nevertheless find differences between mixed and single sex siblings. Dropping gender and birth order in Model 3 shows that mixed sex in itself has no significant impact. This is also true when retaining the variables "Male" and " $2^{\text {nd }}$ born" in Model 4. Yet, motivated by Hypothesis 2, in Model 5 we control more carefully for interaction effects of mixed sex composition with birth order or gender. As we see, both interaction terms ( $2^{\text {nd }}$ born*Mixed sex and Male*Mixed sex) are not significant and do not alter our birth order effect sizes. Therefore, this model shows that there is no difference between mixed and single sex siblings' compositions, which means that we cannot reject our Hypothesis 2 (of finding no effect of the siblings' sex composition).

Besides our main interest in birth order and siblings' sex composition effects, we note from Table 4 two further independent variables that are significant for time preferences. Children from a higher socioeconomic background (with a higher score in the family affluence scale FAS) are more patient (consistent with recent findings by Deckers et al., 2017) and children from families with 3 children are less patient than children from families with 2 children. 
TABLE 4: TIME PREFERENCES

\begin{tabular}{|c|c|c|c|c|c|}
\hline & (1) & (2) & (3) & (4) & (5) \\
\hline \multirow[t]{2}{*}{ Male } & -0.045 & & & -0.035 & -0.092 \\
\hline & $(0.07)$ & & & $(0.07)$ & $(0.09)$ \\
\hline \multirow[t]{2}{*}{$2^{\text {nd }}$ born } & & $0.218 * * *$ & & $0.213 * * *$ & $0.211 * *$ \\
\hline & & $(0.07)$ & & $(0.07)$ & $(0.10)$ \\
\hline \multirow[t]{2}{*}{ Mixed sex } & & & 0.070 & 0.050 & -0.046 \\
\hline & & & $(0.09)$ & $(0.09)$ & $(0.18)$ \\
\hline \multirow[t]{2}{*}{ 2nd born*Mixed sex } & & & & & 0.011 \\
\hline & & & & & $(0.20)$ \\
\hline \multirow[t]{2}{*}{ Male*Mixed sex } & & & & & 0.188 \\
\hline & & & & & $(0.17)$ \\
\hline \multirow[t]{2}{*}{ Risk (std.) } & -0.008 & -0.023 & -0.016 & -0.021 & -0.026 \\
\hline & $(0.06)$ & $(0.06)$ & $(0.05)$ & $(0.06)$ & $(0.06)$ \\
\hline \multirow[t]{2}{*}{ Raven (std.) } & 0.025 & 0.029 & 0.028 & 0.030 & 0.035 \\
\hline & $(0.05)$ & $(0.05)$ & $(0.05)$ & $(0.05)$ & $(0.05)$ \\
\hline \multirow[t]{2}{*}{ Pocket money (std.) } & $0.070 *$ & $0.071^{*}$ & 0.068 & $0.070 *$ & 0.064 \\
\hline & $(0.04)$ & $(0.04)$ & $(0.04)$ & $(0.04)$ & $(0.04)$ \\
\hline \multirow[t]{2}{*}{ FAS (std.) } & $-0.173 * * *$ & $-0.165 * * *$ & $-0.174 * * *$ & $-0.165 * * *$ & $-0.168 * * *$ \\
\hline & $(0.05)$ & $(0.05)$ & $(0.05)$ & $(0.05)$ & $(0.05)$ \\
\hline \multirow[t]{2}{*}{ Mother's age (std.) } & 0.064 & 0.013 & 0.064 & 0.013 & 0.007 \\
\hline & $(0.05)$ & $(0.05)$ & $(0.05)$ & $(0.05)$ & $(0.05)$ \\
\hline \multirow[t]{2}{*}{ No. of Siblings } & $0.201 *$ & $0.188^{*}$ & $0.194 *$ & $0.194 *$ & $0.191 *$ \\
\hline & $(0.10)$ & $(0.10)$ & $(0.10)$ & $(0.10)$ & $(0.10)$ \\
\hline \multirow[t]{2}{*}{ Spacing } & 0.009 & 0.008 & 0.008 & 0.007 & 0.008 \\
\hline & $(0.03)$ & $(0.03)$ & $(0.03)$ & $(0.03)$ & $(0.03)$ \\
\hline \multirow[t]{2}{*}{ constant } & $4.669 * * *$ & $4.551 * * *$ & $4.637 * * *$ & $4.554 * * *$ & $4.584 * * *$ \\
\hline & $(0.15)$ & $(0.15)$ & $(0.15)$ & $(0.14)$ & $(0.13)$ \\
\hline \multirow[t]{2}{*}{ Sigma constant } & $0.663 * * *$ & $0.657 * * *$ & $0.663 * * *$ & $0.656^{* * *}$ & $0.654 * * *$ \\
\hline & $(0.03)$ & $(0.03)$ & $(0.04)$ & $(0.03)$ & $(0.03)$ \\
\hline No. of Obs. & 311 & 311 & 311 & 311 & 311 \\
\hline Pseudo R2 & 0.037 & 0.047 & 0.037 & 0.048 & 0.049 \\
\hline Prob $>$ chi $2 / F$ & 0.002 & 0.000 & 0.003 & 0.000 & 0.000 \\
\hline \multicolumn{6}{|c|}{ Wald tests for joint effects (p-values) } \\
\hline \multirow{2}{*}{\multicolumn{5}{|c|}{$\begin{array}{l}H_{0}: \text { no birth order effect in mixed sex families }\left(\beta_{2 n d}+\beta_{\text {interaction } 1}=0\right) \\
H_{0}: \text { no gender effect in mixed sex families }\left(\beta_{\text {gender }}+\beta_{\text {interaction } 2}=0\right)\end{array}$}} & 0.133 \\
\hline & & & & & $H_{0}:$ no gender effect in mixed sex families $\left(\beta_{\text {gender }}+\beta_{\text {interaction } 2}=0\right)$ \\
\hline
\end{tabular}

\section{B. Risk preferences}

Table 5 presents the descriptive statistics for our risk preferences experiment. We show the average of the lottery number chosen from Figure 1, where Lottery 1 yielded a sure payment of $€ 4$, while 
Lottery 6 had a 50:50 chance for $€ 9$ or $€ 1$. Higher lottery numbers indicate a larger willingness to take risks, therefore. Overall, we find an average of 2.71 (respectively 2.60 in the complete sample of 525 students $)$. There is a strong gender difference between boys $(\mathrm{M}=3.10)$ and girls $(\mathrm{M}=2.27$; Wilcoxon ranksum test: $\mathrm{z}=-4.282$, Prob $>|\mathrm{z}|=0.0000)$.

TABLE 5: RISK PREFERENCES (AVERAGE LOTTERY NUMBER)

\begin{tabular}{llllll}
\hline \hline & All & \multicolumn{2}{c}{ Boys } & \multicolumn{2}{c}{ Girls } \\
& & Single sex & Mixed sex & Single sex & Mixed sex \\
$1^{\text {st }}$ born & 2.577 & 2.578 & 3.842 & 2.083 & 2.56 \\
$2^{\text {nd }}$ born & 2.833 & 3.189 & 3.667 & 2.5 & 1.967 \\
All (mixed/single) & & 2.884 & 3.755 & 2.292 & 2.264 \\
All & 2.709 & & 3.104 & & 2.269 \\
\hline \hline
\end{tabular}

Notes: The numbers indicate the average lottery number chosen from Figure 1. Higher numbers imply more risk taking.

The average lottery number for first born children is 2.58 , compared to 2.83 for second born. This difference is not significant $(z=-1.367$, Prob $>|z|=0.1717)$. The Tobit regression analysis ${ }^{7}$ in Table 6 confirms the significant differences between boys and girls in our sample (Model 1), and indicates no birth order effect (Model 2). Therefore we have to reject our Hypothesis 3a) that de-identification might trigger a birth order effect. Rather, Model 2 in Table 6 looks as if social learning might make first and second born children indistinguishable in their risk preferences. Yet, in Hypothesis 4 we were arguing that the siblings' sex composition should matter for risk preferences. Model 3 in Table 6 offers a first piece of evidence that this is (weakly significantly) the case. But most importantly we consider again Model 5 that includes the interaction terms between siblings' sex composition and gender, respectively birth order. We find that second born children are significantly less risk averse than first born children in single sex compositions, while in mixed sex compositions the birth order effect is negative (-0.676), but not significant. This suggests that in single-sex compositions the process of de-identification yields a significant birth order effect. We also note from Model 5 that the gender effect in mixed sex compositions is significantly larger than in single sex compositions (2.585 compared to 1.014). Hence, we confirm Hypothesis 4 that birth order effects depend on the sibling's sex composition. Furthermore, our results suggest that the underlying mechanism is not social learning, but that de-identification differs with the sibling's sex composition: in single sex compositions, de-identification seems to work by birth order, whereas in mixed sex compositions gender lets siblings differentiate from each other, independent of birth order.

\footnotetext{
${ }^{7}$ Our results are robust to using alternatively an ordered probit regression (since the lottery number as the dependent variable is an ordinal variable). In Appendix B we show that ordered probit yields qualitatively identical results. This invariance to the regression technique also applies to the discussion of trust preferences later in this section.
} 


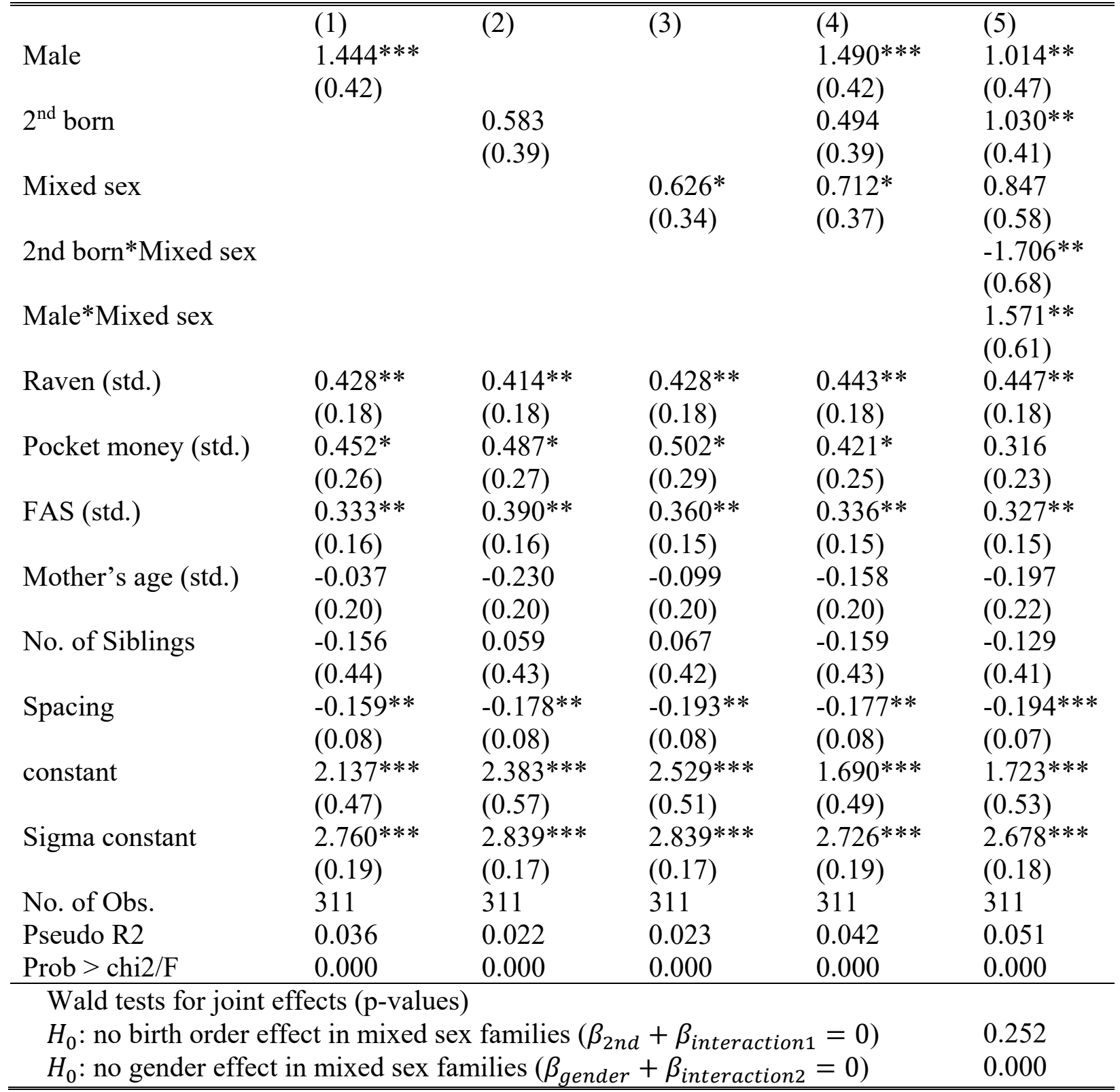

Notes: Dependent variable is the risk level. Control variables are spacing, number of siblings, monthly pocket money, cognitive reflection (raven), socio-economic background (FAS and age of mother. Monthly pocket money, cognitive reflection (raven), socioeconomic background (FAS) and age of mother are standardized (std.). Robust standard errors clustered at the classroom level are given below the coefficient in parentheses.

*** Significant at the 1 percent level.

** Significant at the 5 percent level.

* Significant at the 10 percent level.

Four further variables in Table 6 are also significant. Children who answer more raven matrices correctly, who receive more pocket money and who come from a better socioeconomic background (FAS) are in general more willing to take risks. The spacing between first and second born (in years) has a decreasing impact on risk taking. 


\section{Trust and Trustworthiness}

The data about trust are given in Table 7 . The average amount sent is $€ 1.30$ (respectively $€ 1.31$ in the complete sample of 525 students: $€ 1.31)$. It differs largely between boys (€1.38) and girls ( $€ 1.21$; Wilcoxon ranksum test: $\mathrm{z}=-2.774$, Prob $>|z|=0.0055)$. Comparing first born children $(€ 1.22)$ and second born children $(€ 1.38)$ also reveals a significant difference $(z=-2.474$, Prob $>|z|=0.0134)$. The Tobit regression analysis in Table 8 supports both findings: Boys send more than girls (Model 1) and second born children send more than first born children (Model 2). This confirms Hypothesis 5 regarding trust.

TABLE 7: TRUST (AMOUNT SENT AS SENDER, IN EUROS)

\begin{tabular}{lcllll}
\hline \hline & All & \multicolumn{2}{c}{ Boys } & \multicolumn{2}{c}{ Girls } \\
& & Single sex & Mixed sex & Single sex & Mixed sex \\
$1^{\text {st }}$ born & 1.215 & 1.227 & 1.421 & 1.188 & 1.08 \\
$2^{\text {nd }}$ born & 1.381 & 1.434 & 1.593 & 1.261 & 1.283 \\
All (mixed/single) & & 1.331 & 1.507 & 1.225 & 1.182 \\
All & 1.298 & & 1.377 & & 1.377 \\
\hline \hline
\end{tabular}

Next, we look again how the siblings' sex composition interacts with gender and with birth order. From Model 5 of Table 8 we note second born children are more trusting (i.e., send more money in the trust game) in both types of sex composition and that there is no significant difference in this birth order effect between single sex and mixed sex compositions. The gender effect seems to originate from the mixed sex compositions, as only the joint effect of "Male" plus "Male*Mixed sex" is significantly different from zero. This confirms part of Hypothesis 6, such that boys trust more if they have sisters, and girls trust less if they have brothers. In single sex compositions there is no gender difference in trust, however.

Two background variables are significant in Table 8. Children who answer more matrices correctly are more trusting (which is reminiscent of findings for adults in Dohmen et al., 2010), and trust is reduced if the spacing (in years) between first and second born children increases. 


\begin{tabular}{|c|c|c|c|c|c|}
\hline & (1) & (2) & (3) & (4) & (5) \\
\hline \multirow[t]{2}{*}{ Male } & $0.240 * *$ & & & $0.263 * *$ & 0.157 \\
\hline & $(0.11)$ & & & $(0.12)$ & $(0.12)$ \\
\hline \multirow[t]{2}{*}{$2^{\text {nd }}$ born } & & $0.226 * *$ & & $0.220 * *$ & $0.221 * *$ \\
\hline & & $(0.11)$ & & $(0.11)$ & $(0.10)$ \\
\hline \multirow[t]{2}{*}{ Mixed sex } & & & 0.133 & 0.151 & -0.011 \\
\hline & & & $(0.11)$ & $(0.11)$ & $(0.16)$ \\
\hline \multirow[t]{2}{*}{ 2nd born*Mixed sex } & & & & & 0.007 \\
\hline & & & & & $(0.18)$ \\
\hline \multirow[t]{2}{*}{ Male*Mixed sex } & & & & & $0.360^{*}$ \\
\hline & & & & & $(0.19)$ \\
\hline \multirow[t]{2}{*}{ Risk (std.) } & $0.091^{*}$ & $0.108^{*}$ & $0.113 *$ & 0.072 & 0.062 \\
\hline & $(0.05)$ & $(0.06)$ & $(0.06)$ & $(0.05)$ & $(0.05)$ \\
\hline \multirow[t]{2}{*}{ Raven (std.) } & $0.084 *$ & $0.081 *$ & $0.080^{*}$ & $0.091^{*}$ & $0.100 * *$ \\
\hline & $(0.05)$ & $(0.04)$ & $(0.05)$ & $(0.05)$ & $(0.05)$ \\
\hline \multirow[t]{2}{*}{ Pocket money (std.) } & -0.005 & 0.001 & -0.004 & -0.007 & -0.019 \\
\hline & $(0.04)$ & $(0.04)$ & $(0.04)$ & $(0.04)$ & $(0.04)$ \\
\hline \multirow[t]{2}{*}{ FAS (std.) } & 0.014 & 0.029 & 0.019 & 0.024 & 0.020 \\
\hline & $(0.06)$ & $(0.06)$ & $(0.06)$ & $(0.06)$ & $(0.06)$ \\
\hline \multirow[t]{2}{*}{ Mother's age (std.) } & $0.101 *$ & 0.041 & 0.092 & 0.048 & 0.037 \\
\hline & $(0.06)$ & $(0.07)$ & $(0.06)$ & $(0.07)$ & $(0.07)$ \\
\hline \multirow[t]{2}{*}{ No. of Siblings } & 0.100 & 0.129 & 0.138 & 0.090 & 0.090 \\
\hline & $(0.16)$ & $(0.15)$ & $(0.16)$ & $(0.15)$ & $(0.15)$ \\
\hline \multirow[t]{2}{*}{ Spacing } & $-0.047 *$ & $-0.051 *$ & $-0.053 *$ & $-0.053 *$ & $-0.052 *$ \\
\hline & $(0.03)$ & $(0.03)$ & $(0.03)$ & $(0.03)$ & $(0.03)$ \\
\hline \multirow[t]{2}{*}{ Constant } & $1.387 * * *$ & $1.366^{* * *}$ & $1.437 * * *$ & $1.242 * * *$ & $1.290 * * *$ \\
\hline & $(0.20)$ & $(0.20)$ & $(0.21)$ & $(0.20)$ & $(0.20)$ \\
\hline \multirow[t]{2}{*}{ Sigma constant } & $0.884 * * *$ & $0.885 * * *$ & $0.890 * * *$ & $0.876^{* * *}$ & $0.873 * * *$ \\
\hline & $(0.06)$ & $(0.06)$ & $(0.06)$ & $(0.06)$ & $(0.06)$ \\
\hline No. of Obs. & 311 & 311 & 311 & 311 & 311 \\
\hline Pseudo R2 & 0.028 & 0.027 & 0.024 & 0.036 & 0.039 \\
\hline Prob $>$ chi $2 / F$ & 0.000 & 0.000 & 0.004 & 0.000 & 0.000 \\
\hline \multicolumn{6}{|c|}{ Wald tests for joint effects (p-values) } \\
\hline \multirow{2}{*}{\multicolumn{5}{|c|}{$\begin{array}{l}H_{0}: \text { no birth order effect in mixed sex families }\left(\beta_{2 n d}+\beta_{\text {interaction } 1}=0\right) \\
H_{0}: \text { no gender effect in mixed sex families }\left(\beta_{\text {gender }}+\beta_{\text {interaction } 2}=0\right)\end{array}$}} & 0.223 \\
\hline & & & & & 0.009 \\
\hline
\end{tabular}

Notes: Dependent variable is the amount send (trust). Control variables are spacing, number of siblings, monthly pocket money, cognitive reflection (raven), socio-economic background (FAS), risk preferences and age of mother. Risk preferences, monthly pocket money, cognitive reflection (raven), socio-economic background (FAS) and age of mother are standardized (std.). Robust standard errors clustered at the classroom level are given below the coefficient in parentheses.

$* * *$ Significant at the 1 percent level.

** Significant at the 5 percent level.

* Significant at the 10 percent level 
The data about trustworthiness, here the share returned, is given in Table 9. The average share returned is 67.8 percent (respectively 69.6 percent in the complete sample of 525 students). ${ }^{8}$ We find no significant differences between boys (69.4 percent) and girls (66.2 percent; Wilcoxon ranksum test: $\mathrm{z}=-0.368$, Prob $>|z|=0.7132)$. Comparing first born children (67.9 percent) and second born children (67.8 percent) also reveals no significant difference $(z=0.334$, Prob $>|z|=0.7384)$. The Tobit regression analysis in Table 10 yields the same findings and we cannot confirm Hypothesis 5 with regard to trustworthiness.

TABLE 9: TRUSTWORTHINESS (SHARE RETURNED TO SENDER)

\begin{tabular}{lllccc}
\hline \hline & All & \multicolumn{2}{c}{ Boys } & \multicolumn{2}{c}{ Girls } \\
& & Single sex & Mixed sex & Single sex & Mixed sex \\
$1^{\text {st }}$ born & 0.679 & 0.694 & 0.629 & 0.720 & 0.600 \\
$2^{\text {nd }}$ born & 0.678 & 0.676 & 0.774 & 0.653 & 0.633 \\
All & & 0.6856 & 0.714 & 0.687 & 0.618 \\
(mixed/single) & & & & & 0.662 \\
All & 0.678 & & 0.694 & & \\
\hline
\end{tabular}

In the next step, we check again whether the siblings' sex composition interacts with gender and birth order. Model 5 of Table 10 reveals that there are differences between mixed sex and single sex families. We find a significant gender effect for mixed sex families, with girls returning less money and boys returning more money in mixed sex families. This confirms the additional part of Hypothesis 6, such that boys are also more trustworthy if they have sisters, and girls are less trustworthy if they have brothers. There are no further significant background variables.

\footnotetext{
${ }^{8}$ Recall that the receiver had gotten the same endowment as the sender. Hence, if receivers return an amount that equalizes payoffs between sender and receiver (in case the initial transfer is larger than zero), then the share returned is 66.6 percent.
} 
TABLE 10 RESUltS: TRUSTWORTHINESS

\begin{tabular}{|c|c|c|c|c|c|}
\hline & (1) & (2) & (3) & (4) & $(5)$ \\
\hline Male & $\begin{array}{l}0.016 \\
(0.03)\end{array}$ & & & $\begin{array}{l}0.015 \\
(0.03)\end{array}$ & $\begin{array}{r}-0.031 \\
(0.05)\end{array}$ \\
\hline 2nd born & & $\begin{array}{l}0.018 \\
(0.05)\end{array}$ & & $\begin{array}{l}0.019 \\
(0.05)\end{array}$ & $\begin{array}{l}-0.019 \\
(0.05)\end{array}$ \\
\hline Mixed sex & & & $\begin{array}{l}-0.014 \\
(0.04)\end{array}$ & $\begin{array}{l}-0.014 \\
(0.04)\end{array}$ & $\begin{array}{c}-0.146^{* *} \\
(0.07)\end{array}$ \\
\hline 2nd born*Mixed sex & & & & & $\begin{array}{l}0.123 \\
(0.09)\end{array}$ \\
\hline Male*Mixed sex & & & & & $\begin{array}{l}0.138^{*} \\
(0.07)\end{array}$ \\
\hline Risk (std.) & $\begin{array}{l}0.018 \\
(0.02)\end{array}$ & $\begin{array}{l}0.019 \\
(0.02)\end{array}$ & $\begin{array}{l}0.020 \\
(0.02)\end{array}$ & $\begin{array}{l}0.018 \\
(0.02)\end{array}$ & $\begin{array}{l}0.018 \\
(0.02)\end{array}$ \\
\hline Raven (std.) & $\begin{array}{l}0.022 \\
(0.02)\end{array}$ & $\begin{array}{l}0.022 \\
(0.02)\end{array}$ & $\begin{array}{l}0.021 \\
(0.02)\end{array}$ & $\begin{array}{l}0.022 \\
(0.02)\end{array}$ & $\begin{array}{l}0.027^{*} \\
(0.02)\end{array}$ \\
\hline Pocket money (std.) & $\begin{array}{l}-0.020 \\
(0.02)\end{array}$ & $\begin{array}{l}-0.020 \\
(0.02)\end{array}$ & $\begin{array}{l}-0.020 \\
(0.02)\end{array}$ & $\begin{array}{l}-0.020 \\
(0.02)\end{array}$ & $\begin{array}{l}-0.022 \\
(0.02)\end{array}$ \\
\hline FAS (std.) & $\begin{array}{l}-0.009 \\
(0.02)\end{array}$ & $\begin{array}{l}-0.008 \\
(0.02)\end{array}$ & $\begin{array}{l}-0.009 \\
(0.02)\end{array}$ & $\begin{array}{l}-0.008 \\
(0.02)\end{array}$ & $\begin{array}{l}-0.011 \\
(0.02)\end{array}$ \\
\hline Mother's age (std.) & $\begin{array}{l}-0.013 \\
(0.03)\end{array}$ & $\begin{array}{l}-0.018 \\
(0.03)\end{array}$ & $\begin{array}{l}-0.014 \\
(0.03)\end{array}$ & $\begin{array}{l}-0.018 \\
(0.03)\end{array}$ & $\begin{array}{l}-0.023 \\
(0.03)\end{array}$ \\
\hline No. of Siblings & $\begin{array}{l}0.024 \\
(0.06)\end{array}$ & $\begin{array}{l}0.026 \\
(0.06)\end{array}$ & $\begin{array}{l}0.026 \\
(0.06)\end{array}$ & $\begin{array}{l}0.024 \\
(0.06)\end{array}$ & $\begin{array}{l}0.019 \\
(0.06)\end{array}$ \\
\hline Spacing & $\begin{array}{r}-0.013 \\
(0.01)\end{array}$ & $\begin{array}{r}-0.013 \\
(0.01)\end{array}$ & $\begin{array}{r}-0.012 \\
(0.01)\end{array}$ & $\begin{array}{r}-0.012 \\
(0.01)\end{array}$ & $\begin{array}{c}-0.010 \\
(0.01)\end{array}$ \\
\hline Constant & $\begin{array}{c}0.673 * * * \\
(0.08)\end{array}$ & $\begin{array}{c}0.670^{* * *} \\
(0.09)\end{array}$ & $\begin{array}{c}0.682 * * * \\
(0.09)\end{array}$ & $\begin{array}{c}0.667 * * * \\
(0.10)\end{array}$ & $\begin{array}{c}0.707 * * * \\
(0.09)\end{array}$ \\
\hline Sigma constant & $\begin{array}{c}0.391 * * * \\
(0.03)\end{array}$ & $\begin{array}{c}0.391 * * * \\
(0.03)\end{array}$ & $\begin{array}{c}0.391 * * * \\
(0.03)\end{array}$ & $\begin{array}{c}0.391 * * * \\
(0.03)\end{array}$ & $\begin{array}{c}0.388 * * * \\
(0.03)\end{array}$ \\
\hline No. of Obs. & 311 & 311 & 311 & 311 & 311 \\
\hline Pseudo R2 & 0.015 & 0.015 & 0.015 & 0.016 & 0.027 \\
\hline Prob $>$ chi $2 / F$ & 0.387 & 0.389 & 0.365 & 0.529 & 0.011 \\
\hline $\begin{array}{l}\text { Wald tests for join } \\
H_{0}: \text { no birth order } \\
H_{0}: \text { no gender effe }\end{array}$ & $\begin{array}{l}\text { fects ( } p \text {-valu } \\
\text { ect in mixed } \\
\text { in mixed ser }\end{array}$ & $\begin{array}{l}\mathrm{x} \text { families } \\
\text { milies }\left(\beta_{g e r}\right.\end{array}$ & $\begin{array}{l}+\beta_{\text {interact }} \\
+\beta_{\text {interacti }}\end{array}$ & $\begin{array}{l}=0) \\
=0)\end{array}$ & $\begin{array}{l}0.2001 \\
0.0329\end{array}$ \\
\hline
\end{tabular}




\section{Discussion}

Our general results for time, risk and trust preferences match the typical patterns observed in other studies. On average, our students are risk averse and impatient - like, e.g., in studies with children and teenagers of Bettinger and Slonim (2007), Castillo et al. (2011) or Sutter et al. (2013) - and send more than half of their endowment in the trust game - like the adolescents in the study of Sutter and Kocher (2007). Our findings on gender also resemble earlier results. We find boys to be more risk taking than girls, which is a common finding in the literature (see, e.g., Croson and Gneezy, 2009; Cárdenas et al. 2012; Deckers et al., 2017). In the trust game, boys are more trusting than girls and show differences with regard to trustworthiness, results that are in line with data in Sutter and Kocher (2007). With respect to time preferences, we do not observe gender differences in our sample. In this preference domain, results vary a lot, however. For instance, Dohmen et al. (2010) and Deckers et al. (2017) report boys to be more patient than girls, while Bettinger and Slonim (2007) and Castillo et al. (2011) present the opposite result. So it seems that there is not yet any consensus on whether gender differences in time preferences existent, and if so, in which direction. However, gender per se has not been the main issue of our project.

Rather, the main focus of this paper is to examine the impact of birth order position and of siblings' sex composition on economic preferences. Previous studies have mainly focused on birth order only (Yiannakis, 1976; Courtiol et al., 2009; Sulloway and Zweigenhaft, 2010; Lampi and Nordblom, 2011; Dohmen et al., 2012) and disregarded the siblings' sex composition. According to evidence from developmental psychology - as discussed in section II - both birth order and siblings' sex composition can have a major influence on the development of preferences and the impact might be different for each. We therefore add to the existing literature by jointly analyzing the influence of birth order and siblings' sex composition as well as extending the analysis to adolescents and we improve internal validity by using incentivized experiments.

Regarding time preferences, we find that second born children are less patient than first born children. This is in line with Hypothesis 1 a) and gives support for the de-identification theory, where siblings tend to develop different behaviors in order to be distinguishable for the parents and so get more attention and resources from them. Our finding mirrors one particular result by Lampi and Nordblom (2011) who found in their survey study with adults that middle born children - in their study typically the second born children - are the least patient ones. In line with Hypothesis 2 the birth order effects do not depend on the siblings' sex composition and remain significant when controlling for the latter.

Regarding risk preferences, we find no significant birth order effect between first and second born children. Therefore, we have to reject Hypothesis 3 a), which postulated that first born children are 
more risk averse. At first sight, our result seems to stand in contrast to other studies that have reported a birth order effect on risk taking (Sulloway and Zweigenhaft, 2010; Lampi and Nordblom, 2011). Yet, when we add the siblings' sex composition to our analysis, we see that the effect of birth order is considerably more differentiated than postulated in previous studies (see Hypothesis 4). Our results show that birth order effects are only visible when siblings have the same sex. In such a single sex environment, we confirm that second born children are less risk averse than first born children. In families with both girls and boys, children seem to distinguish themselves from their siblings rather via their gender than via their birth order position. Here we find de-identification through gender, and not through birth order. Boys with sisters are more risk taking than girls with brothers, regardless of their birth order. Our study therefore substantiates the finding that children are more likely to follow gender-specific stereotypes in mixed sex environments than in single sex ones (Lawson et al., 2015). Both effects, birth order for single sex environment and gender for mixed sex environment are compatible with the theory of de-identification among siblings.

Regarding trust preferences, we find that second born children send more money in the trust game than first born children, but return equal shares. This is in line with the first part of Hypothesis 5 and confirms the findings for trust by Courtiol et al. (2009) who studied students around the age of 20. We additionally show that the results are also significant when risk preferences are included as control variable and when the siblings' sex composition is taken into account. As discussed above, we find gender differences in trust, with boys trusting more than girls. When we add the siblings' sex composition to our analysis, we find that gender differences in trust levels are larger (and significant) in mixed sex environments than in single sex environments. Boys and girls with same sex siblings send the same amount on average while boys with sisters send more than girls with brothers. With regard to trustworthiness we do not find a general birth order effect. Yet, including the sibling's sex composition reveals the same pattern as for trust, with boys (girls) returning more (less) money coming from mixed sex families compared to single sex families. This means that the development of trust and trustworthiness depends on the environment, in our case the birth order position and the siblings' gender. This finding is in line with Hypothesis 6 and lends support to social learning theory in the domain of trust and trustworthiness, with the underlying mechanism that boys with sisters learn that they can trust (their sisters), while girls with brothers learn the opposite. 


\section{Conclusion}

In our paper we focused on two aspects within the family context which can help to explain differences in economic preferences between children: birth order and siblings' sex composition. We ran incentivized experiments with several hundreds of 16 year old tenth graders. To the best of our knowledge, our study is the first looking at birth order and siblings' sex composition together in a large set of economic preferences (of risk, time and trust preferences) and investigating humans in a particularly interesting period of development, i.e., in adolescence.

We find that both aspects, birth order and siblings' sex composition, matter. However, it depends on the preference which aspect is of particular importance. Starting with time preferences, we find strong birth order effects, such that second born children are less patient than first born children. This effect is independent of the gender of the siblings, so it does not matter whether siblings have the same sex or not. For risk and trust preferences, however, the siblings' sex composition does make a difference, and for these two types of economic preferences it would be misleading to only look at birth order, but disregard sex composition. Regarding risk preferences, children identify with the gender stereotype in mixed sex environments where boys are much more willing to take risks than girls, irrespective of birth order. In a single sex environment, this is not the case, and there birth order generates de-identification of (same sex) siblings. Concerning trust preferences, we find that second born children send more money in the trust game than first born children in both types of siblings' sex composition and that the gender differences in trust and trustworthiness are larger in mixed sex than in single sex environments.

Our results are important in three different ways. First, we show that time preferences vary with regard to birth order, with first born children being more patient. Since studies show that time preferences are a good predictor for important life-time outcomes (Khwaja et al., 2006; Chabris et al., 2008; Castillo et al., 2011; 2018; Sutter et al., 2013; Golsteyn et al., 2014), these differences may be one explanation why birth order effects have been found in field behavior related to education (Black et al., 2005; Booth and Kee, 2008; Härkönen, 2014), earnings (Behrman and Taubman, 1986; Björklund and Jäntti, 2012), or health (Black et al., 2016).

Second we contribute to the discussion about de-identification within a family. In case of time preferences where no gender differences are visible, de-identification by birth order is important. We show, however, that in the case of risk preferences where we find strong gender differences, deidentification by birth order is only visible in single sex environments. When siblings have different sexes, de-identification by gender seems to be more important. So far, de-identification by birth order has been discussed exclusively for risk preferences and sex composition has not been taken into account (e.g., Sulloway and Zweigenhaft, 2010). Our results highlight that in case of the availability 
of gender specific stereotypes (e.g., Siegrist et al., 2002; Eckel and Grossman, 2002, 2008) siblings' sex composition might have a larger impact than the birth order position. This result is important as Lampi and Nordblom (2011) have shown that risk preferences can explain parts of the earnings differences between siblings and our results also relate to a recent study by Cools and Patacchini (2017) who report that women with brothers earn less than women with sisters.

Third, we show that in case of trust social learning is important. Sutter and Kocher (2007) have shown that trust increases for children with age and is relatively stable during adulthood. Our results show that the family context works as one important environment to form trust behavior of children and it highlights that it matters with whom children interact in their families for how much they trust in others and how trustworthy they are.

Overall, therefore, the family context with respect to birth order and the sex composition of children has an important influence on the shape of children's economic preferences and can help explain the large heterogeneity in these preferences across subjects. Given that risk, time and trust preferences are so important for lifetime outcomes, we consider our project as one further step to improve our understanding of how family composition matters for the formation of economic preferences. 


\section{REFERENCES}

Alan, S., Baydar, N., Boneva, T., Crossley, T. F., and Ertac, S. 2017. Transmission of risk preferences from mothers to daughters. Journal of Economic Behavior \& Organization, 134, 60-77.

Alan, S and Ertac, 2. 2018. Fostering Patience in the Classroom: Results from Randomized Educational Intervention, Journal of Political Economy, 126, 1865-1911.

Almås, Ingvild, Alexander W. Cappelen, Kjell G. Salvanes, Erik Ø. Sørensen, and Bertil Tungodden. 2016. What Explains the Gender Gap in College Track Dropout? Experimental and Administrative Evidence. American Economic Review, 106(5): 296-302.

Barclay, K., \& Kolk, M. 2015. Birth order and mortality: A population-based cohort study. Demography, 52(2), 613-639.

Bauer, M., Chytilová, J. and Pertold-Gebicka, B. 2014. Parental background and other-regarding preferences in children. Experimental Economics, 17(1), 24-46.

Behrman, J. R., and Taubman, P. 1986. Birth Order, Schooling, and Earnings. Journal of Labor Economics, 4(3), S121-S145.

Berg, J., Dickhaut, J., and McCabe, K. 1995. Trust, reciprocity, and social history. Games and economic behavior, 10(1), 122-142.

Bettinger, E., and Slonim, R. 2007. Patience among children. Journal of Public Economics, 91(1-2), $343-363$.

Bjerkedal, T., Kristensen, P., Skjeret, G. A., and Brevik, J. I. 2007. Intelligence test scores and birth order among young Norwegian men (conscripts) analyzed within and between families. Intelligence, 35(5), 503-514.

Björklund, A., and Jäntti, M. 2012. How important is family background for labor-economic outcomes? Labour Economics, 19(4), 465-474.

Black, S.E., Devereux, P.J., and Salvanes, K.G. 2005. The more the merrier? The effect of family size and birth order on children's education. The Quarterly Journal of Economics, 120(2), 669700.

Black, S.E., Devereux, P.J., and Salvanes, K.G. 2011. Older and Wiser? Birth order and IQ of young men. CESifo Economic Studies 57(1), 103-120.

Black, S. E., Devereux, P. J., and Salvanes, K. G. 2016. Healthy (?), wealthy, and wise: Birth order and adult health. Economics \& Human Biology, 23, 27-45

Booth, A. L., and Kee, H. J. 2009. Birth order matters: the effect of family size and birth order on educational attainment. Journal of Population Economics, 22(2), 367-397.

Boyce, W., Torsheim, T., Currie, C., and Zambon, A. 2006. The Family Affluence Scale as a Measure of National Wealth: Validation of an Adolescent Self-Report Measure. Social Indicators Research, $78(3), 473-487$. 
Buchan, N.R., Croson, R.T.A. and Solnick, S. 2008. Trust and gender: An examination of behavior and beliefs in the Investment Game. Journal of Economic Behavior and Organization, 68(3-4), 466-476.

Buhrmester, D. 1992. The developmental courses of sibling and peer relationships. Children's sibling relationships: Developmental and clinical issues, 19-40.

Castillo, M., Ferraro, P. J., Jordan, J. L., and Petrie, R. 2011. The today and tomorrow of kids: Time preferences and educational outcomes of children. Journal of Public Economics, 95(11-12), 13771385 .

Castillo, M., Jordan, J. L., and Petrie, R. 2018. Children's rationality, risk attitudes and field behavior. European Economic Review, 102, 62-81.

Cárdenas, J. C., Dreber, A., Von Essen, E., and Ranehill, E. 2012. Gender differences in competitiveness and risk taking: Comparing children in Colombia and Sweden. Journal of Economic Behavior and Organization, 83(1), 11-23.

Cesearini, D.. 2009. Genetic Variation in Preferences for Giving and Risk Taking. Quarterly Journal of Economics, 124(2), 809-842.

Chabris, C. F., Laibson, D., Morris, C. L., Schuldt, J. P., and Taubinsky, D. 2008. Individual laboratory-measured discount rates predict field behavior. Journal of Risk and Uncertainty, 37(23), 237-269.

Chassin, L., Presson, C. C., Sherman, S. J., and Edwards, D. A. 1990. The natural history of cigarette smoking: predicting young-adult smoking outcomes from adolescent smoking patterns. Health Psychology, 9(6), 701.

Cools, A., and Patacchini, E. 2017. Sibling Gender Composition and Women's Wages. Institute for the Study of Labor (IZA) Discussion Paper 11001.

Courtiol, A., Raymond, M., and Faurie, C. 2009. Birth order affects behaviour in the investment game: firstborns are less trustful and reciprocate less. Animal Behaviour, 78(6), 1405-1411.

Croson, R., and Gneezy, U. 2009. Gender Differences in Preferences. Journal of Economic Literature, 47(2), 448-474.

Crouter A.C., McGuire, S.A., McHale, S.M., and Updegraff, K.A. 1995. Congruence between Mothers' and Fathers' Differential Treatment of Siblings: Links with Family Relations and Children's Well-Being. Child Development, 66(1), 116-128.

Crouter, A. C., Helms-Erikson, H., Updegraff, K., and McHale, S. M. 1999. Conditions Underlying Parents' Knowledge about Children's Daily Lives in Middle Childhood: Between-and WithinFamily Comparisons. Child Development, 70(1), 246-259. 
Currie, C. E., Elton, R. A., Todd, J., and Platt, S. 1997. Indicators of socioeconomic status for adolescents: The WHO Health Behaviour in School-aged Children Survey. Health Education Research, 12(3), 385-397.

Dai, X., and Heckman, J. J. 2013. Older siblings' contributions to young child's cognitive skills. Economic modelling, 35, 235-248.

Dave, C., Eckel, C. C., Johnson, C. A., and Rojas, C. 2010. Eliciting risk preferences: When is simple better? Journal of Risk and Uncertainty, 41(3), 219-243.

Deckers, T., Falk, A., Kosse, F., Pinger, P., and Schildberg-Hörisch, H. 2017. Socio-economic status and inequalities in children's IQ and economic preferences. IZA Discussion Paper No. 11158.

Dohmen, T., Falk, A., Huffman, D., and Sunde, U. 2010. Are Risk Aversion and Impatience Related to Cognitive Ability? American Economic Review, 100(3), 1238-1260.

Dohmen, T., Falk, A., Huffman, D., and Sunde, U. 2012. The intergenerational transmission of risk and trust attitudes. The Review of Economic Studies, 79(2), 645-677.

Eckel, C. C., and Grossman, P. J. 2002. Sex differences and statistical stereotyping in attitudes toward financial risk. Evolution and Human Behavior, 23(4), 281-295.

Eckel, C. C., and Grossman, P. J. 2008. Forecasting risk attitudes: An experimental study using actual and forecast gamble choices. Journal of Economic Behavior and Organization, 68(1), 1-17.

Fehr, E., Kirchsteiger, G., and Riedl, A. 1993. Does fairness prevent market clearing? An experimental investigation. The Quarterly Journal of Economics, 108(2), 437-459.

Feinberg, M.E., McHale, S.M., Crouter, A.C., and Cumsille, P. 2003 Sibling Differentiation: Sibling and Parent Relationship Trajectories in Adolescence. Child Development, 74(5), 1261-1274.

Feinberg, M.E., Solmeyer, A.R., Hostetler, M.L., Sakuma, K.L., Jones, D., and McHale, S.M. 2013. Siblings Are Special: Initial Test of a New Approach for Preventing Youth Behavior Problems. Journal of Adolescent Health, 53(2), 166-173.

Fischbacher, U. 2007. z-Tree: Zurich toolbox for ready-made economic experiments. Experimental economics, 10(2), 171-178.

Golsteyn, B. H., Grönqvist, H., and Lindahl, L. 2014. Adolescent Time Preferences Predict Lifetime Outcomes. The Economic Journal, 124(580), F739-F761.

Grotevant, H. D. 1978. Sibling constellations and sex typing of interests in adolescence. Child Development, 540-542.

Hardin, R. 2001. Conceptions and explanations of trust. In K. S. Cook (Ed.), Russell Sage foundation series on trust, Vol. 2. Trust in society (pp. 3-39). New York: Russell Sage Foundation.

Härkönen, J. 2014. Birth Order Effects on Educational Attainment and Educational Transitions in West Germany. European Sociological Review, 30(2), 166-179. 
Hatton, T. J., and Martin, R. M. 2010. Fertility decline and the heights of children in Britain, 18861938. Explorations in Economic History, 47(4), 505-519.

Heckman, J.J., Stixrud, J., and Urzua, S. 2006. The Effects of Cognitive and Noncognitive Abilities on Labor Market Outcomes and Social Behavior. Journal of Labor Economics, 24(3), 411-482.

Hertwig, R., Davis, J. N., and Sulloway, F. J. 2002. Parental investment: how an equity motive can produce inequality. Psychological Bulletin, 128(5), 728-745.

Hetherington, E. M. 1991. Presidential address: Families, lies, and videotapes. Journal of Research on Adolescence, 1, 323-348.

Jacobs, B. S., and Moss, H. A. 1976. Birth order and sex of sibling as determinants of mother-infant interaction. Child Development, 315-322.

Kerschbamer, R., Sutter, M., and Dulleck, U. 2017. How social preferences shape incentives in (experimental) markets for credence goods. The Economic Journal, 127(600), 393-416.

Khwaja, A., Sloan, F., and Salm, M. 2006. Evidence on preferences and subjective beliefs of risk takers: The case of smokers. International Journal of Industrial Organization, 24(4), 667-682.

Knack, S., and Keefer, P. 1997. Does social capital have an economic payoff? A cross-country investigation. The Quarterly Journal of Economics, 112(4), 1251-1288.

Koch, H. L. 1956. Some emotional attitudes of the young child in relation to characteristics of his sibling. Child Development, 27, 393-426.

Kosse, F., and Pfeiffer, F. 2012. Impatience among preschool children and their mothers. Economics Letters, 115(3), 493-495.

Lahav, E., Benzion, U., and Shavit, T. 2010. Subjective time discount rates among teenagers and adults: Evidence from Israel. The Journal of Socio-Economics, 39(4), 458-465.

Lampi, E., and Nordblom, K. 2011. Gender and birth-order differences in time and risk preferences and decisions. Working Papers in Economics, University of Gothenburg, Department of Economics. (388).

Landesportal Schleswig-Holstein, 2017, Bericht der Landesregierung: Schulische Bildung in Schleswig-Holstein 2017. Drucksache 18/5280 accessible at: http://www.schleswigholstein.de/DE/Fachinhalte/S/schulsystem/Downloads/bildungsbericht_2017.pdf?_blob=public ationFile\&v=3, last access February 2, 2018.

Lawson, K. M., Crouter, A. C., and McHale, S. M. 2015. Links between family gender socialization experiences in childhood and gendered occupational attainment in young adulthood. Journal of Vocational Behavior, 90, 26-35.

Lundborg, P., Nystedt, P., and Rooth, D. O. 2014. Height and earnings: The role of cognitive and noncognitive skills. Journal of Human Resources, 49(1), 141-166. 
Lytton, H. and Romney, D. M. 1991. Parents' differential socialization of boys and girls: A metaanalysis. Psychological Bulletin, 109, 267-297.

McHale, S. M., Crouter, A. C., and Tucker, C. J. 1999. Family context and gender role socialization in middle childhood: Comparing girls to boys and sisters to brothers. Child Development, 70(4), 990-1004.

McHale, S. M., Updegraff, K. A., Jackson-Newsom, J., Tucker, C. J., and Crouter, A. C. 2000. When does parents' differential treatment have negative implications for siblings?. Social Development, 9(2), 149-172.

McHale, S. M., Crouter, A. C., and Tucker, C. J. 2001. Free-time activities in middle childhood: Links with adjustment in early adolescence. Child Development, 72(6), 1764-1778.

Meier, S., and Sprenger, C. 2010. Present-biased preferences and credit card borrowing. American Economic Journal: Applied Economics, 2(1), 193-210.

Meier, S., and Sprenger, C. D. 2013. Discounting financial literacy: Time preferences and participation in financial education programs. Journal of Economic Behavior and Organization, $95,159-174$.

Meredith, H. V. 1950. Birth order and body size. II. Neonatal and childhood materials. American Journal of Physical Anthropology, 8(2), 195-224.

Modin, B. 2002. Birth order and mortality: a life-long follow-up of 14,200 boys and girls born in early 20th century Sweden. Social Science \& Medicine, 54(7), 1051-1064.

Moffitt, T.E., Arseneault, L., Belsky, D., Dickson, N., Hancox, R.J., Harrington, H., Houts, R., Poulton, R., Roberts, B.W., Ross, S., Sears, N.R., Thomsom, W.M., and Caspi, A. 2011. A gradient of childhood self-control predicts health, wealth, and public safety. Proceedings of the National Academy of Sciences, 108(7), 2693-2698.

Okudaira, H., Kinari, Y., Mizutani, N., Ohtake, F., and Kawaguchi, A. 2015. Older sisters and younger brothers: The impact of siblings on preference for competition. Personality and Individual Differences, 82, 81-89.

Price, J. 2008. Parent-Child Quality Time Does Birth Order Matter?. Journal of Human Resources, 43(1), 240-265.

Rust, J., Golombok, S., Hines, M., Johnston, K., Golding, J., and ALSPAC Study Team. 2000. The role of brothers and sisters in the gender development of preschool children. Journal of Experimental Child Psychology, 77(4), 292-303.

Schacter, F. F., Gilutz, G., Shore, E., and Adler, M. 1978. Sibling deidentification judged by mothers: Cross validation and developmental studies. Child Development, 49, 543-546.

Schacter, F. F., Shore, E., Feldman-Rotman, S., Marquis, R. E., and Campbell, S. 1976. Sibling deidentification. Developmental Psychology, 12, 418-427. 
Siegrist, M., Cvetkovich, G., and Gutscher, H. 2002. Risk preference predictions and gender stereotypes. Organizational Behavior and Human Decision Processes, 87(1), 91-102.

Stoneman, Z., Brody, G. H., and MacKinnon, C. E. 1986. Same-sex and cross-sex siblings: Activity choices, roles, behavior, and gender stereotypes. Sex Roles, 15(9), 495-511.

Sulloway, F.J. 1995. Birth Order and Evolutionary Psychology: A Meta-Analytic Overview. Psychological Inquiry, 6(1), 75-80.

Sulloway, F. J. 1996. Born to rebel: Birth order, family dynamics, and creative lives. Pantheon Books.

Sulloway, F. J., and Zweigenhaft, R. L. 2010. Birth order and risk taking in athletics: A meta-analysis and study of major league baseball. Personality and Social Psychology Review, 14(4), 402-416.

Sutter, M., and Kocher, M. G. 2007. Trust and trustworthiness across different age groups. Games and Economic Behavior, 59(2), 364-382.

Sutter, M., Kocher, M. G., Glätzle-Rützler, D., and Trautmann, S. T. 2013. Impatience and Uncertainty: Experimental Decisions Predict Adolescents' Field Behavior. American Economic Review, 103(1), 510-531.

Sutton-Smith, B., and Rosenberg, B. G. 1970. The Sibling. NewYork: Holt, Rinehart \&Winston.

Tucker, C. J., Barber, B. L., and Eccles, J. 1997. Advice about life plans and personal problems in late adolescent sibling relationships. Journal of Youth and Adolescence, 26, 63-76.

Whiteman, S. D., McHale, S. M., and Crouter, A. C. 2007. Competing processes of sibling influence: Observational learning and sibling deidentification. Social Development, 16(4), 642-661.

Wingerd, J. 1970. The relation of growth from birth to 2 years to sex, parental size and other factors, using Rao's method of the transformed time scale. Human Biology, 105-131.

Yiannakis, A. 1976. Delinquent tendencies and participation in an organized sports program. Research Quarterly. American Alliance for Health, Physical Education and Recreation, 47(4), 845-849.

Zak, P. J., and Knack, S. 2001. Trust and growth. The Economic Journal, 111(470), 295-321.

Zyphur, M.J., Narayanan, J., Arvey, R.D. and G. Alexander. 2009. The Genetics of Economic Risk Preferences, Journal of Behavioral Decision Making, 22, 367-377 


\section{Appendix (for online use)}

\section{A. Experimental instructions}

In the following we will conduct five experiments. In each experiment you have to make an economic decision. At the end of the five experiments the computer will determine by chance which one out of the five experiments will be relevant for your payment. If you have made multiple decisions in the respective experiment, the computer will choose one of the decisions. This means that you will receive the payment of one of the decisions in one of the experiments. Since you don't know which decision will be relevant later on, you should treat each decision as if it was the relevant one. As you will see, the sums paid are notable. Please consider your decision with care. There is no right or wrong, we are interested in your personal opinion. Please do not talk to your fellow students throughout the entire experiment. Should you have a question at any point, please don't hesitate to raise your finger. One of the conductors of the experiment will come to you and answer your question. 
As in the example below, in this situation you have to decide between column A or B.

Example:

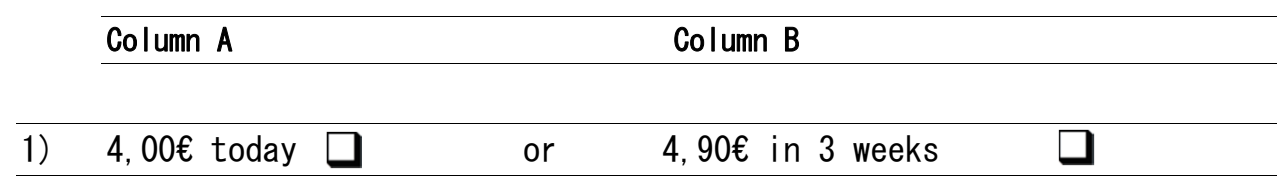

Payment „today“ means that you will receive the money today at the end of the experiment.

Payment "in 3 weeks" means that you will receive the money in exactly 3 weeks.

Payment "in 6 weeks" means that you will receive the money in exactly 6 weeks.

There are 2 pages with 20 rows each. You start with the first row and work your way down answering row by row. For each row you choose between 4 Euros (column A) and a different amount 3 weeks later (column B). Please consider the date of payment. The amount in column A remains the same for each row. The amount in column B rises constantly with each row. Once you have chosen column B once, you should not switch back to column A. 


\section{Situation 1}

For each row, please choose between 4 Euros today and the rising amount in 3 weeks.

Once you have chosen column B for the first time, you should not switch to column A anymore.

\begin{tabular}{|c|c|c|c|c|c|}
\hline & Column A & & & Column B & \\
\hline 1) & $4 €$ today & $\square$ & or & $4,00 €$ in 3 weeks & $\square$ \\
\hline 2) & $4 €$ today & $\square$ & or & $4,10 €$ in 3 weeks & $\square$ \\
\hline 3) & $4 €$ today & $\square$ & or & $4,20 €$ in 3 weeks & $\square$ \\
\hline 4) & $4 €$ today & $\square$ & or & $4,30 €$ in 3 weeks & $\square$ \\
\hline 5) & $4 €$ today & $\square$ & or & $4,40 €$ in 3 weeks & $\square$ \\
\hline 6) & $4 €$ today & $\square$ & or & $4,50 €$ in 3 weeks & $\square$ \\
\hline 7) & $4 €$ today & $\square$ & or & $4,60 €$ in 3 weeks & $\square$ \\
\hline 8) & $4 €$ today & $\square$ & or & $4,70 €$ in 3 weeks & $\square$ \\
\hline 9) & $4 €$ today & $\square$ & or & $4,80 €$ in 3 weeks & $\square$ \\
\hline 10) & $4 €$ today & $\square$ & or & $4,90 €$ in 3 weeks & $\square$ \\
\hline 11) & $4 €$ today & $\square$ & or & $5,00 €$ in 3 weeks & $\square$ \\
\hline 12) & $4 €$ today & $\square$ & or & $5,10 €$ in 3 weeks & $\square$ \\
\hline 13) & $4 €$ today & $\square$ & or & $5,20 €$ in 3 weeks & $\square$ \\
\hline 14) & $4 €$ today & $\square$ & or & $5,30 €$ in 3 weeks & $\square$ \\
\hline 15) & $4 €$ today & $\square$ & or & $5,40 €$ in 3 weeks & $\square$ \\
\hline 16) & $4 €$ today & $\square$ & or & $5,50 €$ in 3 weeks & $\square$ \\
\hline 17) & $4 €$ today & $\square$ & or & $5,60 €$ in 3 weeks & $\square$ \\
\hline 18) & $4 €$ today & $\square$ & or & $5,70 €$ in 3 weeks & $\square$ \\
\hline 19) & $4 €$ today & $\square$ & or & $5,80 €$ in 3 weeks & $\square$ \\
\hline 20) & $4 €$ today & $\square$ & or & $5,90 €$ in 3 weeks & $\square$ \\
\hline
\end{tabular}


Situation 2

For each row, please choose between 4 Euros in 3 weeks and the rising amount in 6 weeks.

Once you have chosen column B for the first time, you should not switch to column A anymore.

\begin{tabular}{|c|c|c|c|c|c|}
\hline & Column A & & & Column B & \\
\hline 21) & $4 €$ in 3 weeks & $\square$ & or & $4,00 €$ in 6 weeks & $\square$ \\
\hline 22) & $4 €$ in 3 weeks & $\square$ & or & $4,10 €$ in 6 weeks & $\square$ \\
\hline 23) & $4 €$ in 3 weeks & $\square$ & or & $4,20 €$ in 6 weeks & $\square$ \\
\hline 24) & $4 €$ in 3 weeks & $\square$ & or & $4,30 €$ in 6 weeks & $\square$ \\
\hline 25) & $4 €$ in 3 weeks & $\square$ & or & $4,40 €$ in 6 weeks & $\square$ \\
\hline 26) & $4 €$ in 3 weeks & $\square$ & or & $4,50 €$ in 6 weeks & $\square$ \\
\hline 27) & $4 €$ in 3 weeks & $\square$ & or & $4,60 €$ in 6 weeks & $\square$ \\
\hline 28) & $4 €$ in 3 weeks & $\square$ & or & $4,70 €$ in 6 weeks & $\square$ \\
\hline 29) & $4 €$ in 3 weeks & $\square$ & or & $4,80 €$ in 6 weeks & $\square$ \\
\hline 30) & $4 €$ in 3 weeks & $\square$ & or & $4,90 €$ in 6 weeks & $\square$ \\
\hline 31) & $4 €$ in 3 weeks & $\square$ & or & $5,00 €$ in 6 weeks & $\square$ \\
\hline 32) & $4 €$ in 3 weeks & $\square$ & or & $5,10 €$ in 6 weeks & $\square$ \\
\hline 33) & $4 €$ in 3 weeks & $\square$ & or & $5,20 €$ in 6 weeks & $\square$ \\
\hline 34) & $4 €$ in 3 weeks & $\square$ & or & $5,30 €$ in 6 weeks & $\square$ \\
\hline 35) & $4 €$ in 3 weeks & $\square$ & or & $5,40 €$ in 6 weeks & $\square$ \\
\hline 36) & $4 €$ in 3 weeks & $\square$ & or & $5,50 €$ in 6 weeks & $\square$ \\
\hline 37) & $4 €$ in 3 weeks & $\square$ & or & $5,60 €$ in 6 weeks & $\square$ \\
\hline 38) & $4 €$ in 3 weeks & $\square$ & or & $5,70 €$ in 6 weeks & $\square$ \\
\hline 39) & $4 €$ in 3 weeks & $\square$ & or & $5,80 €$ in 6 weeks & $\square$ \\
\hline 40) & $4 €$ in 3 weeks & $\square$ & or & $5,90 €$ in 6 weeks & $\square$ \\
\hline
\end{tabular}




\section{Decision sheet $R$}

In this situation, you have to choose one out of six coins. Each coin has two sides - orange and pink - showing amounts in Euro. For the coin you choose - no matter which one it is - you have a 50\% chance to be paid out the orange side and a $50 \%$ chance to be paid out the pink side. Depending on which side faces up, you will receive the amount indicated on the coin (in Euro).

Please choose the coin that appeals best to you.
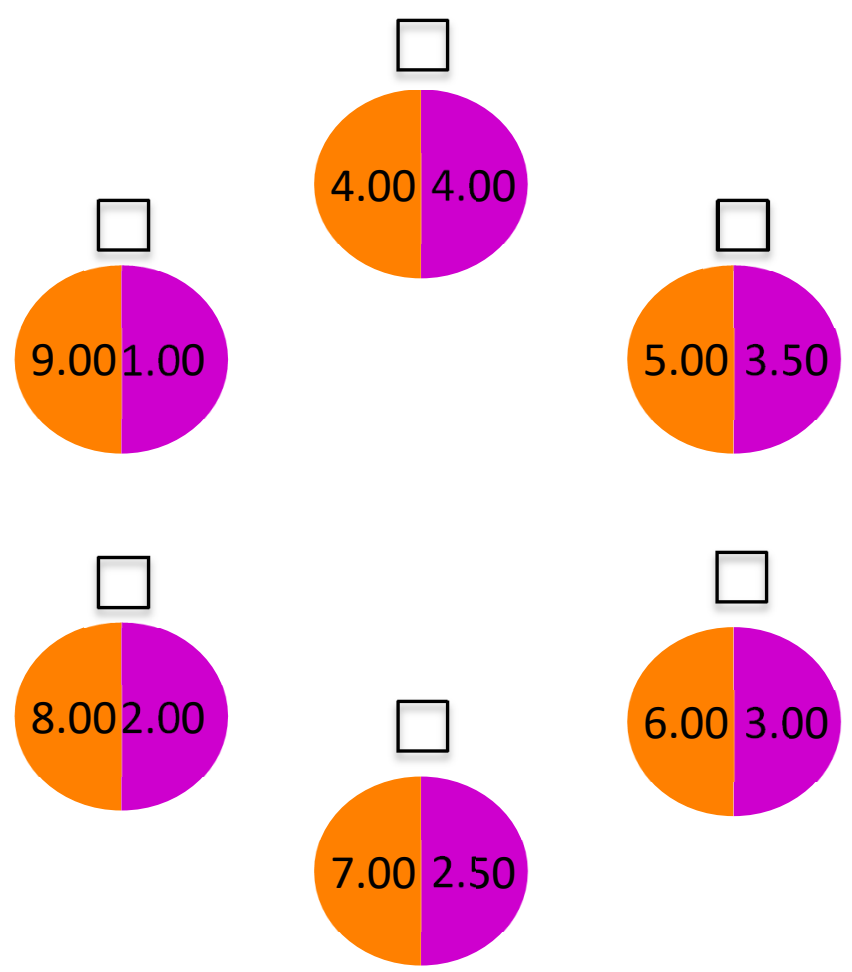


\section{Decision sheet $T$}

In this situation you do not only make a decision for yourself but also for another person from this class. For that purpose, the computer will assign you to a person from this class. You will be shown two situations in which you have to make a decision. The computer will determine your role and the role of your partner at the end of the experiment at random.

\section{Situation 1}

Initially, you and the other person receive $2.00 €$ each. You now have the opportunity to send to your partner between $0 €$ and $2.00 €$.

The money sent will be tripled by the organizer. The other person thus receives 3 times as much as you sent. The other person then sends back to you any amount he or she desires. This amount can be between $0 €$ and $8.00 €(2.00 € * 3+2.00 €=8.00 €)$ and will not be tripled.

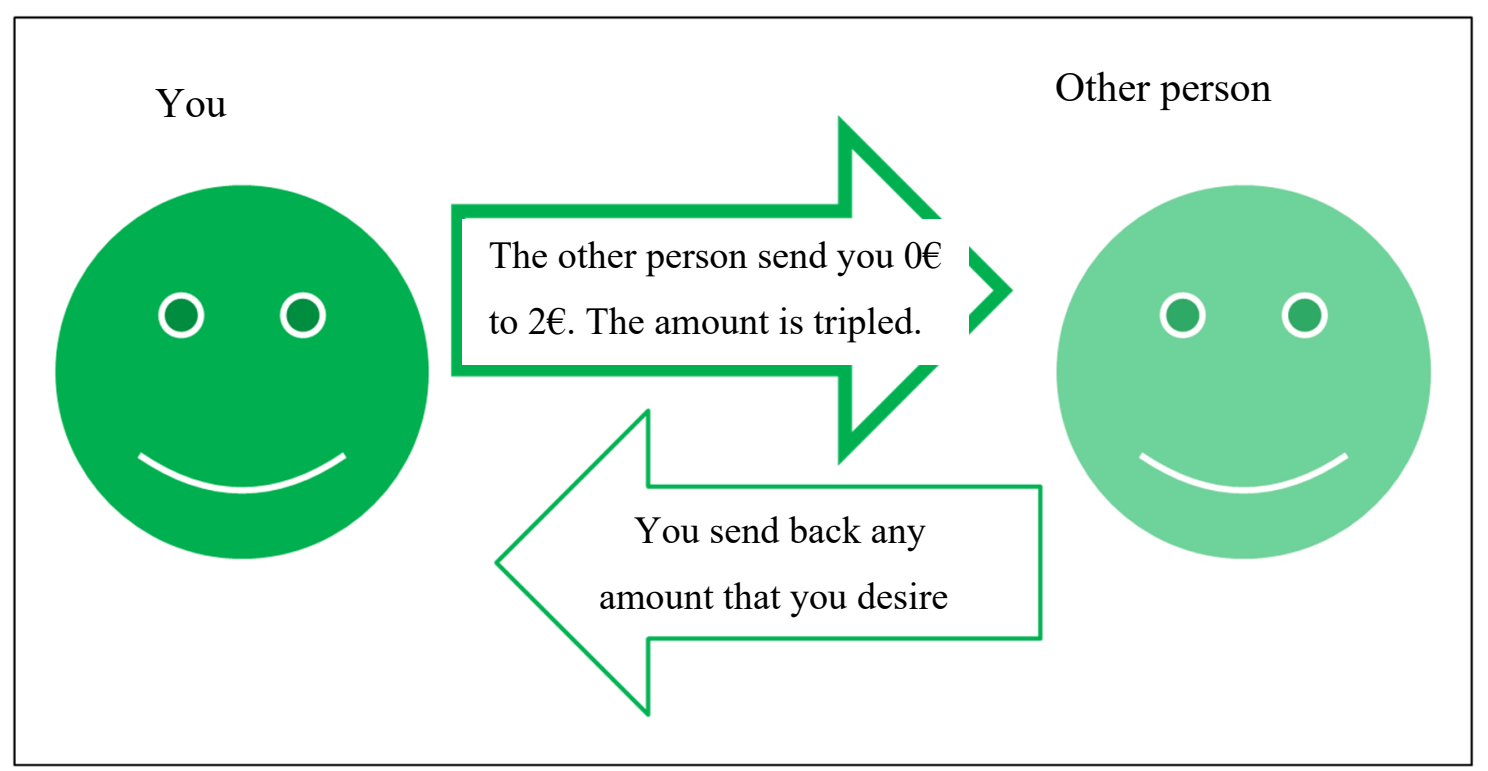

Your payment amounts to $=$

$2 €-$ transfer to the other person + transfer from the other person to you

The other person's payment amounts to=

$2 €+$ transfer from you - transfer to you

How much money do you wish to send to the other person? 


\section{Situation 2}

Initially, you and the other person receive $2.00 €$ each. The other person now has the opportunity to send to you between $0 €$ and $2.00 €$. The money sent is tripled by the organizer. You thus receive 3 times as much as the other person sent to you.

You send back any amount that you desire. This amount can be between $0 €$ and $8.00 €(2.00 € * 3+2.00 €=$ $8.00 €)$ and will not be tripled.

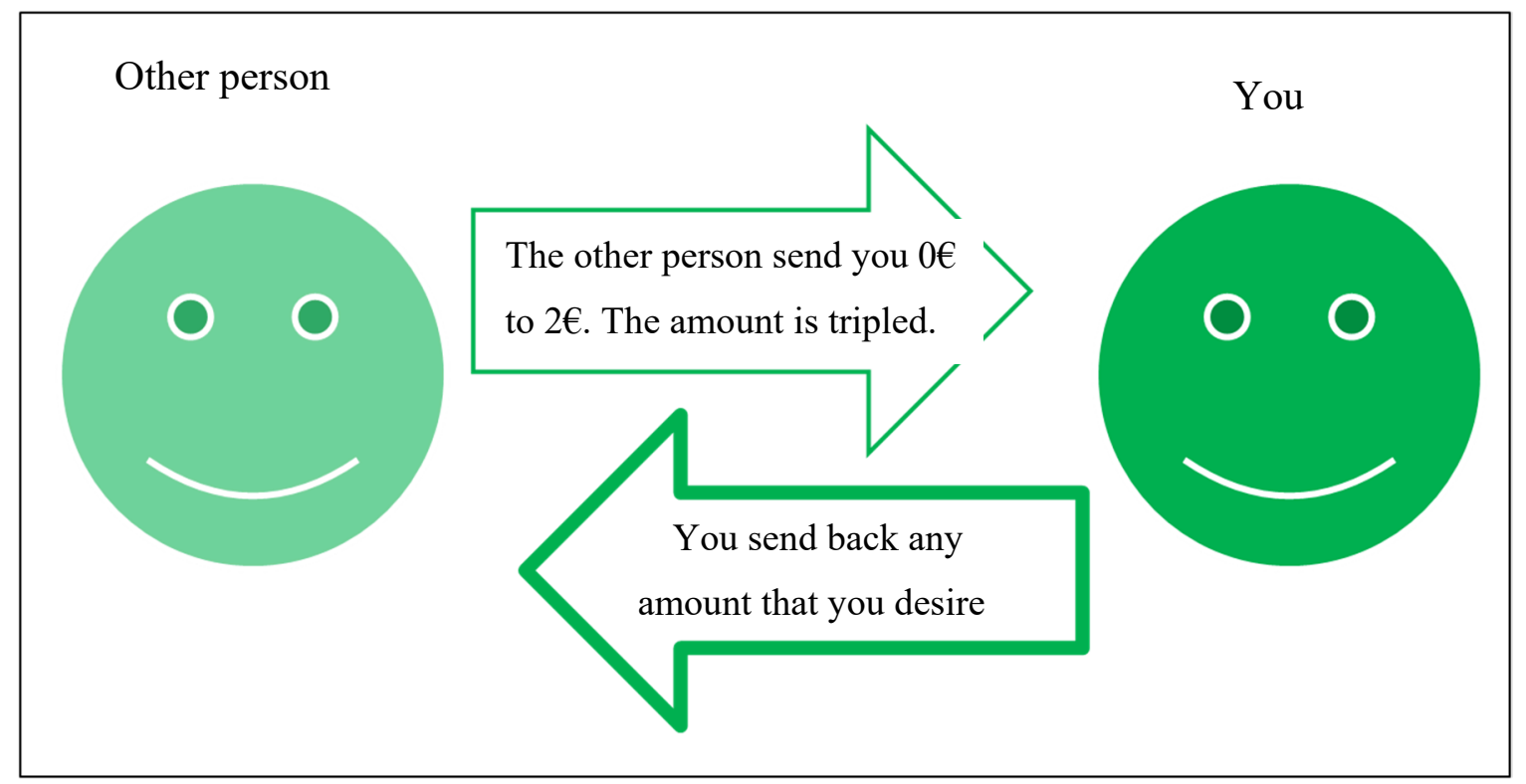

\section{Your payment amounts to $=$}

$2 €+$ transfer from the other person to you - transfer to the other person from you

The other person's payment amounts to=

$2 €-$ transfer to you + transfer from you

\section{Please choose how much you wish to send back.}

a) The other person sends you $0 €$.

How much money do you wish to send back?

b) The other person sends you $0.50 €$. Hence, you receive $1.50 €$ (after tripling).

How much money do you wish to send back?

c) The other person sends you $1.00 €$. Hence, you receive $3.00 €$ (after tripling).

How much money do you wish to send back?

d) The other person sends you $1.50 €$. Hence, you receive $4.50 €$ (after tripling).

How much money do you wish to send back?

e) The other person sends you $2.00 €$. Hence, you receive $6.00 €$ (after tripling).

How much money do you wish to send back? 


\section{Decision sheet $L$}

Depending on the role of the dice you can now receive different amounts.

If you

- role a 1 you receive $1 €$

- role a 2 you receive $2 €$

- role a 3 you receive $3 €$

- role a 4 you receive $4 €$

- role a 5 you receive $5 €$

- role a 6/ a star you receive $0 €$

Please roll the dice in a manner that ensures only you can see the result (e.g. cover the dice with your hand). Remember the number rolled, and then turn the dice on the star (6).

Now fill in the number you rolled.

Which number did you roll? 


\section{General questionnaire}

1.) Gender: $\square$ male $\square$ female

2.) How old are you?

3.) How tall are you?

4.) What's your weight?

5.) In your last report, which grade did you receive in mathematics?

6.) In your last report, which grade did you receive in German?

7.) In your last report, which grade did you receive in biology?

$\square$ not chosen

8.) In your last report, which grade did you receive in physics?

$\square$ not chosen

9.) Do you have siblings you grew up with?

$\square$ no siblings $\square$ no siblings I grew up with $\square$ only younger siblings $\square$ older and younger siblings

$\square$ only older siblings

10.) If you have siblings, please note for each sibling age, gender, and your family relation to them, even if you didn't grow up together.

1. Age:

Gender: $\square$ male

family relation:

$\square$ natural sibling

$\square$ female

$\square$ half sibling

2. Age:

Gender: $\square$ male

family relation:

$\square$ stepsibling

$$
\square \text { female }
$$

$\square$ natural sibling

3. Age:

$$
\text { Gender: } \square \text { male }
$$

family relation:

$\square$ half sibling

$\square$ stepsibling

(age:

$$
\square \text { female }
$$

4. Age:

Gender: $\square$ male

$$
\square \text { female }
$$

family relation:

$\square$ natural sibling

$\square$ half sibling

$\square$ stepsibling

5. Age:
Gender: $\square$ male

$$
\square \text { female }
$$

family relation:

$\square$ natural sibling

$\square$ half sibling

$\square$ stepsibling

$\square$ natural sibling

$\square$ half sibling

$\square$ stepsibling

11.) Do your parents live together? $\square$ Yes $\square$ No

12.) How old is your mother?

13.) How old is your father?

14.) Does your mother work? $\square$ Yes $\square$ No $\square$ I don't know

15.) Does your father work? $\square$ Yes $\square$ No $\square$ I don't know

16.) Does your family have a migrant background? $\square$ Yes $\square$ No $\square$ I don’t know 
17.) How would you rate the financial situation of your family relative to your fellow students'? $\square$ much worse $\square$ worse $\square$ equal $\square$ better $\square$ much better

18.) How many cars does your family possess?

$\square 0 \quad \square 1 \quad \square 2 \quad \square 3$ or more

19.) How many computers (tablets, laptops included) does your family possess?

$\square 0 \quad \square 1 \quad \square 2 \quad \square 3$ or more

20.) How many books does your family possess?

$\square$ 0-10 $11-25 \square$ 26-100 $\square$ 101-200 $\square$ 201-500 $\square$ more than 500

21.) Do you have an own room? $\square$ yes $\square$ no

22.) How often have you traveled as a family during the last two months?

$\square 0 \quad \square 1 \quad \square 2 \quad \square 3$ or more

23.) Do you smoke? $\square$ never $\square$ rarely $\square$ sometimes $\square$ regularly

24.) Do you drink alcohol? $\square$ never $\square$ rarely $\square$ sometimes $\square$ regularly

25.) How much pocket money do you get each month?

26.) Do you work? $\square$ Yes $\square$ No

27.) If yes, how much do you earn each month?

$\square 0 €-10 € \square 10 €-50 € \quad \square 50 €-100 € \quad \square$ more than $100 €$

28.) What do you spend most of your pocket money on?
$\square$ mobile phone bills
$\square$ video games $\square$ clothes
$\square$ magazines
$\square$ cinema $\square$ going out
$\square$ food and beverages
$\square$ sweets $\square$ beauty products
$\square$ music
$\square$ sports
$\square$ concerts
$\square$ cigarettes
$\square$ alcohol
$\square$ toys
$\square$ saving
$\square$ other: 


\section{B. Robustness Checks}

\section{Regression models}

To check whether our results are robust to the use of alternative regression models we re-do our regression analysis for risk preferences and trust. We use an ordered Probit regression since the lottery number as well as the amount send in the trust game is an ordinal variable. Table B.1 shows the results for risk preferences, while Table B. 2 shows the results for trust. In both cases we can confirm the results found in our previous analysis. 
TABLE B.1: RoBUSTNESS CHECK: RISK PREFERENCES (ORDERED PROBIT)

\begin{tabular}{|c|c|c|c|c|c|}
\hline & (1) & (2) & (3) & (4) & $(5)$ \\
\hline \multirow[t]{2}{*}{ Male } & $0.531 * * *$ & & & $0.555 * * *$ & $0.392 * *$ \\
\hline & $(0.17)$ & & & $(0.17)$ & $(0.19)$ \\
\hline \multirow[t]{2}{*}{$2^{\text {nd }}$ born } & & 0.212 & & 0.188 & $0.384 * *$ \\
\hline & & $(0.14)$ & & $(0.14)$ & $(0.15)$ \\
\hline \multirow[t]{2}{*}{ Mixed sex } & & & $0.221^{*}$ & $0.263^{*}$ & 0.315 \\
\hline & & & $(0.12)$ & $(0.14)$ & $(0.22)$ \\
\hline \multicolumn{2}{|l|}{ Interaction } & & & & $-0.615 * *$ \\
\hline \multicolumn{2}{|l|}{ 2nd born*Mixed sex } & & & & $(0.25)$ \\
\hline \multicolumn{2}{|l|}{ Interaction } & & & & $0.568 * *$ \\
\hline \multicolumn{2}{|l|}{ Men $*$ Mixed sex } & & & & $(0.22)$ \\
\hline \multirow[t]{2}{*}{ Raven (std.) } & $0.160 * *$ & $0.151 * *$ & $0.156 * *$ & $0.168 * * *$ & $0.172 * *$ \\
\hline & $(0.06)$ & $(0.06)$ & $(0.06)$ & $(0.07)$ & $(0.07)$ \\
\hline \multirow[t]{2}{*}{ Pocket money (std.) } & $0.158 *$ & $0.166^{*}$ & $0.171^{*}$ & $0.148^{*}$ & 0.113 \\
\hline & $(0.09)$ & $(0.09)$ & $(0.10)$ & $(0.09)$ & $(0.09)$ \\
\hline \multirow[t]{2}{*}{ FAS (std.) } & $0.133 * *$ & $0.149 * * *$ & $0.139 * * *$ & $0.136^{* * *}$ & $0.135 * *$ \\
\hline & $(0.06)$ & $(0.06)$ & $(0.05)$ & $(0.05)$ & $(0.06)$ \\
\hline \multirow[t]{2}{*}{ Mother's age (std.) } & -0.019 & -0.088 & -0.040 & -0.065 & -0.080 \\
\hline & $(0.07)$ & $(0.07)$ & $(0.07)$ & $(0.08)$ & $(0.08)$ \\
\hline \multirow[t]{2}{*}{ No. of Siblings } & -0.066 & 0.013 & 0.016 & -0.068 & -0.058 \\
\hline & $(0.16)$ & $(0.15)$ & $(0.15)$ & $(0.16)$ & $(0.15)$ \\
\hline \multirow[t]{2}{*}{ Spacing } & $-0.058 * *$ & $-0.064 * *$ & $-0.069 * *$ & $-0.066^{* *}$ & $-0.073 * * *$ \\
\hline & $(0.03)$ & $(0.03)$ & $(0.03)$ & $(0.03)$ & $(0.03)$ \\
\hline \multirow[t]{2}{*}{ Cut 1 constant } & $-0.410 * *$ & $-0.485^{* *}$ & $-0.538 * * *$ & -0.247 & -0.260 \\
\hline & $(0.17)$ & $(0.19)$ & $(0.18)$ & $(0.18)$ & $(0.20)$ \\
\hline \multirow[t]{2}{*}{ Cut 2 constant } & 0.059 & -0.029 & -0.083 & 0.227 & 0.220 \\
\hline & $(0.17)$ & $(0.20)$ & $(0.18)$ & $(0.18)$ & $(0.20)$ \\
\hline \multirow[t]{2}{*}{ Cut 3 constant } & $0.730 * * *$ & $0.623 * * *$ & $0.569 * * *$ & $0.907 * * *$ & $0.908 * * *$ \\
\hline & $(0.17)$ & $(0.20)$ & $(0.18)$ & $(0.19)$ & $(0.20)$ \\
\hline \multirow[t]{2}{*}{ Cut 4constant } & $0.880 * * *$ & $0.768 * * *$ & $0.714 * * *$ & $1.058 * * *$ & $1.062 * * *$ \\
\hline & $(0.19)$ & $(0.22)$ & $(0.20)$ & $(0.20)$ & $(0.22)$ \\
\hline \multirow[t]{2}{*}{ constant } & $1.282 * * *$ & $1.160 * * *$ & $1.106^{* * *}$ & $1.467 * * *$ & $1.483 * * *$ \\
\hline & $(0.22)$ & $(0.24)$ & $(0.21)$ & $(0.23)$ & $(0.24)$ \\
\hline No. of Obs. & 311 & 311 & 311 & 311 & 311 \\
\hline Pseudo R2 & 0.040 & 0.025 & 0.025 & 0.047 & 0.056 \\
\hline Prob $>$ chi $2 / F$ & 0.000 & 0.000 & 0.000 & 0.000 & 0.000 \\
\hline \multicolumn{6}{|c|}{ Wald tests for joint effects ( $p$-values) } \\
\hline \multirow{2}{*}{\multicolumn{5}{|c|}{$\begin{array}{l}H_{0}: \text { no birth order effect in mixed sex families }\left(\beta_{2 n d}+\beta_{\text {interaction } 1}=0\right) \\
H_{0}: \text { no gender effect in mixed sex families }\left(\beta_{\text {gender }}+\beta_{\text {interaction } 2}=0\right)\end{array}$}} & 0.280 \\
\hline & & & & & 0.000 \\
\hline
\end{tabular}

Notes: Dependent variable is the risk level. Control variables are spacing, number of siblings, monthly pocket money, cognitive reflection (raven), socio-economic background (FAS and age of mother. Monthly pocket money, cognitive reflection (raven), socio-economic background (FAS) and age of mother are standardized (std.).Robust standard errors clustered at the classroom level are given below the coefficient in parentheses.

*** Significant at the 1 percent level.

** Significant at the 5 percent level.

* Significant at the 10 percent level. 
TABLE B.2: RoBUSTNESS CHECK: TRUST (ORDERED PROBit)

\begin{tabular}{|c|c|c|c|c|c|}
\hline Male & $\begin{array}{l}(1) \\
0.264 * * \\
(0.13)\end{array}$ & (2) & (3) & $\begin{array}{l}(4) \\
0.290 * * \\
(0.13)\end{array}$ & $\begin{array}{l}(5) \\
0.168 \\
(0.14)\end{array}$ \\
\hline $2^{\text {nd }}$ born & & $\begin{array}{l}0.264 * * \\
(0.13)\end{array}$ & & $\begin{array}{l}0.260 * * \\
(0.13)\end{array}$ & $\begin{array}{l}0.245 * * \\
(0.12)\end{array}$ \\
\hline Mixed sex & & & $\begin{array}{l}0.137 \\
(0.12)\end{array}$ & $\begin{array}{l}0.156 \\
(0.13)\end{array}$ & $\begin{array}{l}-0.062 \\
(0.18)\end{array}$ \\
\hline $\begin{array}{l}\text { Interaction } \\
\text { 2nd born*Mixed sex } \\
\text { Interaction } \\
\text { Men * Mixed sex }\end{array}$ & & & & & $\begin{array}{l}0.060 \\
(0.20) \\
0.417^{*} \\
(0.24)\end{array}$ \\
\hline Risk (std.) & $\begin{array}{l}0.088 \\
(0.07)\end{array}$ & $\begin{array}{l}0.107 \\
(0.07)\end{array}$ & $\begin{array}{l}0.112 \\
(0.07)\end{array}$ & $\begin{array}{l}0.067 \\
(0.06)\end{array}$ & $\begin{array}{l}0.058 \\
(0.07)\end{array}$ \\
\hline Raven (std.) & $\begin{array}{l}0.101 * \\
(0.05)\end{array}$ & $\begin{array}{l}0.099 * * \\
(0.05)\end{array}$ & $\begin{array}{l}0.096^{*} \\
(0.05)\end{array}$ & $\begin{array}{l}0.110^{* *} \\
(0.06)\end{array}$ & $\begin{array}{l}0.121 * * \\
(0.06)\end{array}$ \\
\hline Pocket money (std.) & $\begin{array}{l}-0.003 \\
(0.05)\end{array}$ & $\begin{array}{l}0.003 \\
(0.04)\end{array}$ & $\begin{array}{l}-0.002 \\
(0.05)\end{array}$ & $\begin{array}{l}-0.004 \\
(0.04)\end{array}$ & $\begin{array}{l}-0.018 \\
(0.04)\end{array}$ \\
\hline FAS (std.) & $\begin{array}{l}0.011 \\
(0.07)\end{array}$ & $\begin{array}{l}0.027 \\
(0.07)\end{array}$ & $\begin{array}{l}0.016 \\
(0.07)\end{array}$ & $\begin{array}{l}0.023 \\
(0.07)\end{array}$ & $\begin{array}{l}0.017 \\
(0.07)\end{array}$ \\
\hline Mother's age (std.) & $\begin{array}{l}0.123 * \\
(0.07)\end{array}$ & $\begin{array}{l}0.053 \\
(0.08)\end{array}$ & $\begin{array}{l}0.112 \\
(0.07)\end{array}$ & $\begin{array}{l}0.060 \\
(0.08)\end{array}$ & $\begin{array}{l}0.048 \\
(0.08)\end{array}$ \\
\hline No. of Siblings & $\begin{array}{l}0.098 \\
(0.19)\end{array}$ & $\begin{array}{l}0.128 \\
(0.18)\end{array}$ & $\begin{array}{l}0.138 \\
(0.19)\end{array}$ & $\begin{array}{l}0.086 \\
(0.18)\end{array}$ & $\begin{array}{l}0.085 \\
(0.18)\end{array}$ \\
\hline Spacing & $\begin{array}{l}-0.054^{*} \\
(0.03)\end{array}$ & $\begin{array}{l}-0.058^{*} \\
(0.03)\end{array}$ & $\begin{array}{l}-0.059^{*} \\
(0.03)\end{array}$ & $\begin{array}{l}-0.060^{*} \\
(0.03)\end{array}$ & $\begin{array}{l}-0.058^{*} \\
(0.03)\end{array}$ \\
\hline Cut 1 constant & $\begin{array}{l}-1.605^{* * *} \\
(0.23)\end{array}$ & $\begin{array}{l}-1.581^{* * *} \\
(0.23)\end{array}$ & $\begin{array}{l}-1.659 * * * \\
(0.23)\end{array}$ & $\begin{array}{l}-1.456 * * * \\
(0.24)\end{array}$ & $\begin{array}{l}-1.523 * * * \\
(0.24)\end{array}$ \\
\hline Cut 2 constant & $\begin{array}{l}-0.987 * * * \\
(0.24)\end{array}$ & $\begin{array}{l}-0.956^{* * *} \\
(0.24)\end{array}$ & $\begin{array}{l}-1.037 * * * \\
(0.25)\end{array}$ & $\begin{array}{l}-0.832 * * * \\
(0.25)\end{array}$ & $\begin{array}{l}-0.902 * * * \\
(0.25)\end{array}$ \\
\hline Cut 3 constant & $\begin{array}{l}0.149 \\
(0.23)\end{array}$ & $\begin{array}{l}0.180 \\
(0.24)\end{array}$ & $\begin{array}{l}0.092 \\
(0.24)\end{array}$ & $\begin{array}{l}0.313 \\
(0.25)\end{array}$ & $\begin{array}{l}0.248 \\
(0.24)\end{array}$ \\
\hline Cut 4 constant & $\begin{array}{l}0.509^{* *} \\
(0.25)\end{array}$ & $\begin{array}{l}0.538^{* *} \\
(0.25)\end{array}$ & $\begin{array}{l}0.448^{*} \\
(0.26)\end{array}$ & $\begin{array}{l}0.677 * * * \\
(0.26)\end{array}$ & $\begin{array}{l}0.615^{* *} \\
(0.26)\end{array}$ \\
\hline No. of Obs. & 311 & 311 & 311 & 311 & 311 \\
\hline Pseudo R2 & 0.022 & 0.022 & 0.018 & 0.028 & 0.031 \\
\hline Prob $>$ chi $2 / F$ & 0.002 & 0.000 & 0.005 & 0.000 & 0.000 \\
\hline $\begin{array}{l}\text { Wald tests for joint } \\
H_{0} \text { : no birth order e } \\
H_{0} \text { : no gender effe }\end{array}$ & $\begin{array}{l}s \text { ( } p \text {-values) } \\
n \text { mixed sex } \\
\text { hixed sex fa }\end{array}$ & $\begin{array}{l}\text { milies }\left(\beta_{2 n a}\right. \\
\text { ies }\left(\beta_{\text {gender }}\right.\end{array}$ & $\begin{array}{l}\beta_{\text {interaction }} \\
\beta_{\text {interaction }}\end{array}$ & $\begin{array}{l}=0) \\
0)\end{array}$ & $\begin{array}{l}0.145 \\
0.013\end{array}$ \\
\hline
\end{tabular}

Notes: Dependent variable is the amount send (trust).. Control variables are spacing, number of siblings, monthly pocket money, cognitive reflection (raven), socio-economic background (FAS), risk preferences and age of mother. Risk preferences, monthly pocket money, cognitive reflection (raven), socio-economic background (FAS) and age of mother are standardized (std.).Robust standard errors clustered at the classroom level are given below the coefficient in parentheses.

*** Significant at the 1 percent level.

** Significant at the 5 percent level.

* Significant at the 10 percent level. 


\section{Sample specifications}

To check whether our results are robust to a more conservative splitting of the sample with respect to siblings' sex composition, we define single sex as only those cases where all siblings have the same sex also in families with three children. Single sex is here more strictly defined in this setting compared to the sample used in our main analysis. We re-do the analysis for all variables, time preferences, risk preferences and trust in Tables B.3 to B.5 and we can confirm our main results. 
TABle B.3: Robustness CHECK: Time PREFERENCES

\begin{tabular}{|c|c|c|c|c|c|}
\hline & (1) & (2) & (3) & (4) & (5) \\
\hline \multirow[t]{2}{*}{ Male } & -0.045 & & & -0.037 & -0.115 \\
\hline & $(0.07)$ & & & $(0.07)$ & $(0.08)$ \\
\hline \multirow[t]{2}{*}{$2^{\text {nd }}$ born } & & $0.218 * * *$ & & $0.214 * * *$ & $0.213 * *$ \\
\hline & & $(0.07)$ & & $(0.07)$ & $(0.10)$ \\
\hline \multirow[t]{2}{*}{ Mixed sex } & & & 0.060 & 0.029 & -0.080 \\
\hline & & & $(0.10)$ & $(0.09)$ & $(0.16)$ \\
\hline \multicolumn{2}{|l|}{ Interaction } & & & & 0.021 \\
\hline \multicolumn{2}{|l|}{ 2nd born*Mixed sex } & & & & $(0.17)$ \\
\hline \multicolumn{2}{|l|}{ Interaction } & & & & 0.196 \\
\hline \multicolumn{2}{|l|}{ Men * Mixed sex } & & & & $(0.15)$ \\
\hline \multirow[t]{2}{*}{ Risk (std.) } & -0.008 & -0.023 & -0.015 & -0.020 & -0.024 \\
\hline & $(0.06)$ & $(0.06)$ & $(0.05)$ & $(0.06)$ & $(0.06)$ \\
\hline \multirow[t]{2}{*}{ Raven (std.) } & 0.025 & 0.029 & 0.027 & 0.029 & 0.033 \\
\hline & $(0.05)$ & $(0.05)$ & $(0.05)$ & $(0.05)$ & $(0.05)$ \\
\hline \multirow[t]{2}{*}{ Pocket money (std.) } & $0.070 *$ & $0.071 *$ & $0.069 *$ & $0.071 *$ & $0.065 *$ \\
\hline & $(0.04)$ & $(0.04)$ & $(0.04)$ & $(0.04)$ & $(0.04)$ \\
\hline \multirow[t]{2}{*}{ FAS (std.) } & $-0.173 * * *$ & $-0.165 * * *$ & $-0.174 * * *$ & $-0.165 * * *$ & $-0.165 * * *$ \\
\hline & $(0.05)$ & $(0.05)$ & $(0.05)$ & $(0.05)$ & $(0.05)$ \\
\hline \multirow[t]{2}{*}{ Mother's age (std.) } & 0.064 & 0.013 & 0.064 & 0.013 & 0.005 \\
\hline & $(0.05)$ & $(0.05)$ & $(0.05)$ & $(0.05)$ & $(0.05)$ \\
\hline \multirow[t]{2}{*}{ No. of Siblings } & $0.201 *$ & $0.188^{*}$ & 0.165 & 0.180 & 0.171 \\
\hline & $(0.10)$ & $(0.10)$ & $(0.11)$ & $(0.11)$ & $(0.11)$ \\
\hline \multirow[t]{2}{*}{ Spacing } & 0.009 & 0.008 & 0.008 & 0.007 & 0.009 \\
\hline & $(0.03)$ & $(0.03)$ & $(0.03)$ & $(0.03)$ & $(0.03)$ \\
\hline \multirow[t]{2}{*}{ constant } & $4.669 * * *$ & $4.551 * * *$ & $4.667 * * *$ & $4.573 * * *$ & $4.618 * * *$ \\
\hline & $(0.15)$ & $(0.15)$ & $(0.16)$ & $(0.15)$ & $(0.14)$ \\
\hline \multirow[t]{2}{*}{ Sigma constant } & $0.663 * * *$ & $0.657 * * *$ & $0.663 * * *$ & $0.656 * * *$ & $0.655 * * *$ \\
\hline & $(0.03)$ & $(0.03)$ & $(0.04)$ & $(0.03)$ & $(0.03)$ \\
\hline No. of Obs. & 311 & 311 & 311 & 311 & 311 \\
\hline Pseudo R2 & 0.037 & 0.047 & 0.037 & 0.047 & 0.050 \\
\hline Prob $>$ chi $2 / F$ & 0.002 & 0.000 & 0.002 & 0.000 & 0.000 \\
\hline \multicolumn{6}{|c|}{ Wald tests for joint effects (p-values) } \\
\hline \multirow{2}{*}{\multicolumn{5}{|c|}{$H_{0}:$ no birth order effect in mixed sex families $\left(\beta_{2 n d}+\beta_{\text {interaction } 1}=0\right)$}} & 0.049 \\
\hline & & & & & 0.535 \\
\hline
\end{tabular}

Notes: Dependent variable is the future equivalent. Control variables are spacing, number of siblings, monthly pocket money, cognitive reflection (raven), socio-economic background (FAS) and age of mother. Risk preferences, monthly pocket money, cognitive reflection (raven), socio-economic background (FAS) and age of mother are standardized (std.). Robust standard errors clustered at the classroom level are given below the coefficient in parentheses.

*** Significant at the 1 percent level.

** Significant at the 5 percent level.

* Significant at the 10 percent level. 
TABLE B.4: ROBUSTNESS CHECK: RISK PREFERENCES

\begin{tabular}{|c|c|c|c|c|c|}
\hline Male & $\begin{array}{l}(1) \\
1.444 * * * \\
(0.42)\end{array}$ & (2) & (3) & $\begin{array}{l}(4) \\
1.503 * * * \\
(0.43)\end{array}$ & $\begin{array}{l}(5) \\
1.080 * * \\
(0.50)\end{array}$ \\
\hline $2^{\text {nd }}$ born & & $\begin{array}{l}0.583 \\
(0.39)\end{array}$ & & $\begin{array}{l}0.477 \\
(0.39)\end{array}$ & $\begin{array}{l}0.827 * * \\
(0.41)\end{array}$ \\
\hline Mixed sex & & & $\begin{array}{l}0.529 \\
(0.33)\end{array}$ & $\begin{array}{l}0.654^{*} \\
(0.38)\end{array}$ & $\begin{array}{l}0.520 \\
(0.60)\end{array}$ \\
\hline $\begin{array}{l}\text { Interaction } \\
\text { 2nd born*Mixed sex } \\
\text { Interaction } \\
\text { Men * Mixed sex }\end{array}$ & & & & & $\begin{array}{l}-0.752 \\
(0.49) \\
0.982 \\
(0.63)\end{array}$ \\
\hline Raven (std.) & $\begin{array}{l}0.428 * * \\
(0.18)\end{array}$ & $\begin{array}{l}0.414 * * \\
(0.18)\end{array}$ & $\begin{array}{l}0.416^{* * *} \\
(0.18)\end{array}$ & $\begin{array}{l}0.431 * * \\
(0.18)\end{array}$ & $\begin{array}{l}0.423 * * \\
(0.18)\end{array}$ \\
\hline Pocket money (std.) & $\begin{array}{l}0.452 * \\
(0.26)\end{array}$ & $\begin{array}{l}0.487 * \\
(0.27)\end{array}$ & $\begin{array}{l}0.505^{*} \\
(0.28)\end{array}$ & $\begin{array}{l}0.427^{*} \\
(0.24)\end{array}$ & $\begin{array}{l}0.369 \\
(0.22)\end{array}$ \\
\hline FAS (std.) & $\begin{array}{l}0.333 * * \\
(0.16)\end{array}$ & $\begin{array}{l}0.390 * * \\
(0.16)\end{array}$ & $\begin{array}{l}0.362 * * \\
(0.15)\end{array}$ & $\begin{array}{l}0.337 * * \\
(0.15)\end{array}$ & $\begin{array}{l}0.335 * * \\
(0.15)\end{array}$ \\
\hline Mother's age (std.) & $\begin{array}{l}-0.037 \\
(0.20)\end{array}$ & $\begin{array}{l}-0.230 \\
(0.20)\end{array}$ & $\begin{array}{l}-0.103 \\
(0.20)\end{array}$ & $\begin{array}{l}-0.159 \\
(0.20)\end{array}$ & $\begin{array}{l}-0.196 \\
(0.21)\end{array}$ \\
\hline No. of Siblings & $\begin{array}{l}-0.156 \\
(0.44)\end{array}$ & $\begin{array}{l}0.059 \\
(0.43)\end{array}$ & $\begin{array}{l}-0.193 \\
(0.45)\end{array}$ & $\begin{array}{l}-0.483 \\
(0.49)\end{array}$ & $\begin{array}{l}-0.485 \\
(0.48)\end{array}$ \\
\hline Spacing & $\begin{array}{l}-0.159 * * \\
(0.08)\end{array}$ & $\begin{array}{l}-0.178 * * \\
(0.08)\end{array}$ & $\begin{array}{l}-0.186 * * \\
(0.08)\end{array}$ & $\begin{array}{l}-0.170 * * \\
(0.07)\end{array}$ & $\begin{array}{l}-0.167 * * \\
(0.07)\end{array}$ \\
\hline constant & $\begin{array}{l}2.137 * * * \\
(0.47)\end{array}$ & $\begin{array}{l}2.383 * * * \\
(0.57)\end{array}$ & $\begin{array}{l}2.799 * * * \\
(0.53)\end{array}$ & $\begin{array}{l}2.013 * * * \\
(0.56)\end{array}$ & $\begin{array}{l}2.079 * * * \\
(0.60)\end{array}$ \\
\hline Sigma constant & $\begin{array}{l}2.760 * * * \\
(0.19)\end{array}$ & $\begin{array}{l}2.839^{* * *} \\
(0.17)\end{array}$ & $\begin{array}{l}2.843 * * * \\
(0.17)\end{array}$ & $\begin{array}{l}2.729 * * * \\
(0.19)\end{array}$ & $\begin{array}{l}2.713^{* * * *} \\
(0.19)\end{array}$ \\
\hline No. of Obs. & 311 & 311 & 311 & 311 & 311 \\
\hline Pseudo R2 & 0.036 & 0.022 & 0.022 & 0.041 & 0.044 \\
\hline Prob $>$ chi $2 / F$ & 0.000 & 0.000 & 0.000 & 0.000 & 0.000 \\
\hline $\begin{array}{l}\text { Wald tests for joint } \\
H_{0}: \text { no birth order e } \\
H_{0}: \text { no gender effe }\end{array}$ & $\begin{array}{l}\mathrm{s}(\mathrm{p} \text {-values } \\
n \text { mixed se } \\
\text { hixed sex fa }\end{array}$ & $\begin{array}{l}\text { milies }\left(\beta_{2}\right. \\
\text { ies }\left(\beta_{\text {gend }}\right.\end{array}$ & $\begin{array}{l}\beta_{\text {interactio }} \\
\beta_{\text {interactio }}\end{array}$ & $\begin{array}{l}0) \\
0)\end{array}$ & $\begin{array}{l}0.88 \\
0.000 \\
\end{array}$ \\
\hline
\end{tabular}

Notes: Dependent variable is the risk level. Control variables are spacing, number of siblings, monthly pocket money, cognitive reflection (raven), socio-economic background (FAS and age of mother. Monthly pocket money, cognitive reflection (raven), socio-economic background (FAS) and age of mother are standardized (std.).Robust standard errors clustered at the classroom level are given below the coefficient in parentheses.

*** Significant at the 1 percent level.

** Significant at the 5 percent level.

* Significant at the 10 percent level. 
TABle B.5: PANel A - Robustness CheCK: TRUST

\begin{tabular}{|c|c|c|c|c|c|}
\hline & (1) & (2) & (3) & (4) & (5) \\
\hline \multirow[t]{2}{*}{ Male } & $0.240 * *$ & & & $0.269 * *$ & 0.116 \\
\hline & $(0.11)$ & & & $(0.12)$ & $(0.15)$ \\
\hline $2^{\text {nd }}$ born & & $\begin{array}{l}0.226^{* *} \\
(0.11)\end{array}$ & & $\begin{array}{l}0.211^{*} \\
(0.11)\end{array}$ & $\begin{array}{l}0.301 * * \\
(0.12)\end{array}$ \\
\hline Mixed sex & & & $\begin{array}{l}0.158 \\
(0.11)\end{array}$ & $\begin{array}{l}0.175 \\
(0.11)\end{array}$ & $\begin{array}{l}0.083 \\
(0.16)\end{array}$ \\
\hline \multicolumn{2}{|l|}{ Interaction } & & & & -0.180 \\
\hline \multicolumn{2}{|l|}{ 2nd born*Mixed sex } & & & & $(0.19)$ \\
\hline \multicolumn{2}{|l|}{ Interaction } & & & & $0.380^{*}$ \\
\hline \multicolumn{2}{|l|}{ Men * Mixed sex } & & & & $(0.22)$ \\
\hline Risk (std.) & $\begin{array}{l}0.091^{*} \\
(0.05)\end{array}$ & $\begin{array}{l}0.108 * \\
(0.06)\end{array}$ & $\begin{array}{l}0.113 * \\
(0.06)\end{array}$ & $\begin{array}{l}0.072 \\
(0.05)\end{array}$ & $\begin{array}{l}0.062 \\
(0.05)\end{array}$ \\
\hline Raven (std.) & $\begin{array}{l}0.084^{*} \\
(0.05)\end{array}$ & $\begin{array}{l}0.081 * \\
(0.04)\end{array}$ & $\begin{array}{l}0.078^{*} \\
(0.04)\end{array}$ & $\begin{array}{l}0.089 * \\
(0.05)\end{array}$ & $\begin{array}{l}0.092 * * \\
(0.05)\end{array}$ \\
\hline Pocket money (std.) & $\begin{array}{l}-0.005 \\
(0.04)\end{array}$ & $\begin{array}{l}0.001 \\
(0.04)\end{array}$ & $\begin{array}{l}-0.003 \\
(0.04)\end{array}$ & $\begin{array}{l}-0.005 \\
(0.04)\end{array}$ & $\begin{array}{l}-0.021 \\
(0.04)\end{array}$ \\
\hline FAS (std.) & $\begin{array}{l}0.014 \\
(0.06)\end{array}$ & $\begin{array}{l}0.029 \\
(0.06)\end{array}$ & $\begin{array}{l}0.019 \\
(0.06)\end{array}$ & $\begin{array}{l}0.023 \\
(0.05)\end{array}$ & $\begin{array}{l}0.025 \\
(0.06)\end{array}$ \\
\hline Mother's age (std.) & $\begin{array}{l}0.101 * \\
(0.06)\end{array}$ & $\begin{array}{l}0.041 \\
(0.07)\end{array}$ & $\begin{array}{l}0.090 \\
(0.06)\end{array}$ & $\begin{array}{l}0.048 \\
(0.07)\end{array}$ & $\begin{array}{l}0.034 \\
(0.07)\end{array}$ \\
\hline No. of Siblings & $\begin{array}{l}0.100 \\
(0.16)\end{array}$ & $\begin{array}{l}0.129 \\
(0.15)\end{array}$ & $\begin{array}{l}0.059 \\
(0.15)\end{array}$ & $\begin{array}{l}0.002 \\
(0.15)\end{array}$ & $\begin{array}{l}0.001 \\
(0.16)\end{array}$ \\
\hline Spacing & $\begin{array}{l}-0.047^{*} \\
(0.03)\end{array}$ & $\begin{array}{l}-0.051^{*} \\
(0.03)\end{array}$ & $\begin{array}{l}-0.052 * \\
(0.03)\end{array}$ & $\begin{array}{l}-0.052^{*} \\
(0.03)\end{array}$ & $\begin{array}{l}-0.051^{*} \\
(0.03)\end{array}$ \\
\hline constant & $\begin{array}{l}1.387 * * * \\
(0.20)\end{array}$ & $\begin{array}{l}1.366^{* * *} \\
(0.20)\end{array}$ & $\begin{array}{l}1.506 * * * \\
(0.20)\end{array}$ & $\begin{array}{l}1.321 * * * \\
(0.20)\end{array}$ & $\begin{array}{l}1.355^{* * * *} \\
(0.20)\end{array}$ \\
\hline Sigma constant & $\begin{array}{l}0.884 * * * \\
(0.06)\end{array}$ & $\begin{array}{l}0.885^{* * * *} \\
(0.06)\end{array}$ & $\begin{array}{l}0.889 * * * \\
(0.06)\end{array}$ & $\begin{array}{l}0.875^{* * * *} \\
(0.06)\end{array}$ & $\begin{array}{l}0.870^{* * * *} \\
(0.06)\end{array}$ \\
\hline No. of Obs. & 311 & 311 & 311 & 311 & 311 \\
\hline Pseudo R2 & 0.028 & 0.027 & 0.024 & 0.037 & 0.042 \\
\hline Prob $>$ chi $2 / F$ & 0.000 & 0.000 & 0.002 & 0.000 & 0.000 \\
\hline $\begin{array}{l}\text { Wald tests for joint ef } \\
H_{0}: \text { no birth order effe } \\
H_{0}: \text { no gender effect } \\
\end{array}$ & $\begin{array}{l}\text { p-values) } \\
\text { mixed sex f: } \\
\text { ed sex fami }\end{array}$ & $\begin{array}{l}\text { es }\left(\beta_{2 n d}+\right. \\
\beta_{\text {gender }}+ \\
\end{array}$ & $\begin{array}{l}\operatorname{raction} 1= \\
\text { raction } 2=\end{array}$ & & $\begin{array}{l}0.484 \\
0.003 \\
\end{array}$ \\
\hline
\end{tabular}

Notes: Dependent variable is the amount send (trust).. Control variables are number of siblings, monthly pocket money, cognitive reflection (raven), socio-economic background (FAS), risk preferences and age of mother. Risk preferences, monthly pocket money, cognitive reflection (raven), socio-economic background (FAS) and age of mother are standardized (std.). Robust standard errors clustered at the classroom level are given below the coefficient in parentheses.

*** Significant at the 1 percent level.

** Significant at the 5 percent level.

* Significant at the 10 percent level. 
TABle B.5: PANel B - Robustness CheCK: TRUSTWORTHINESS

(1)

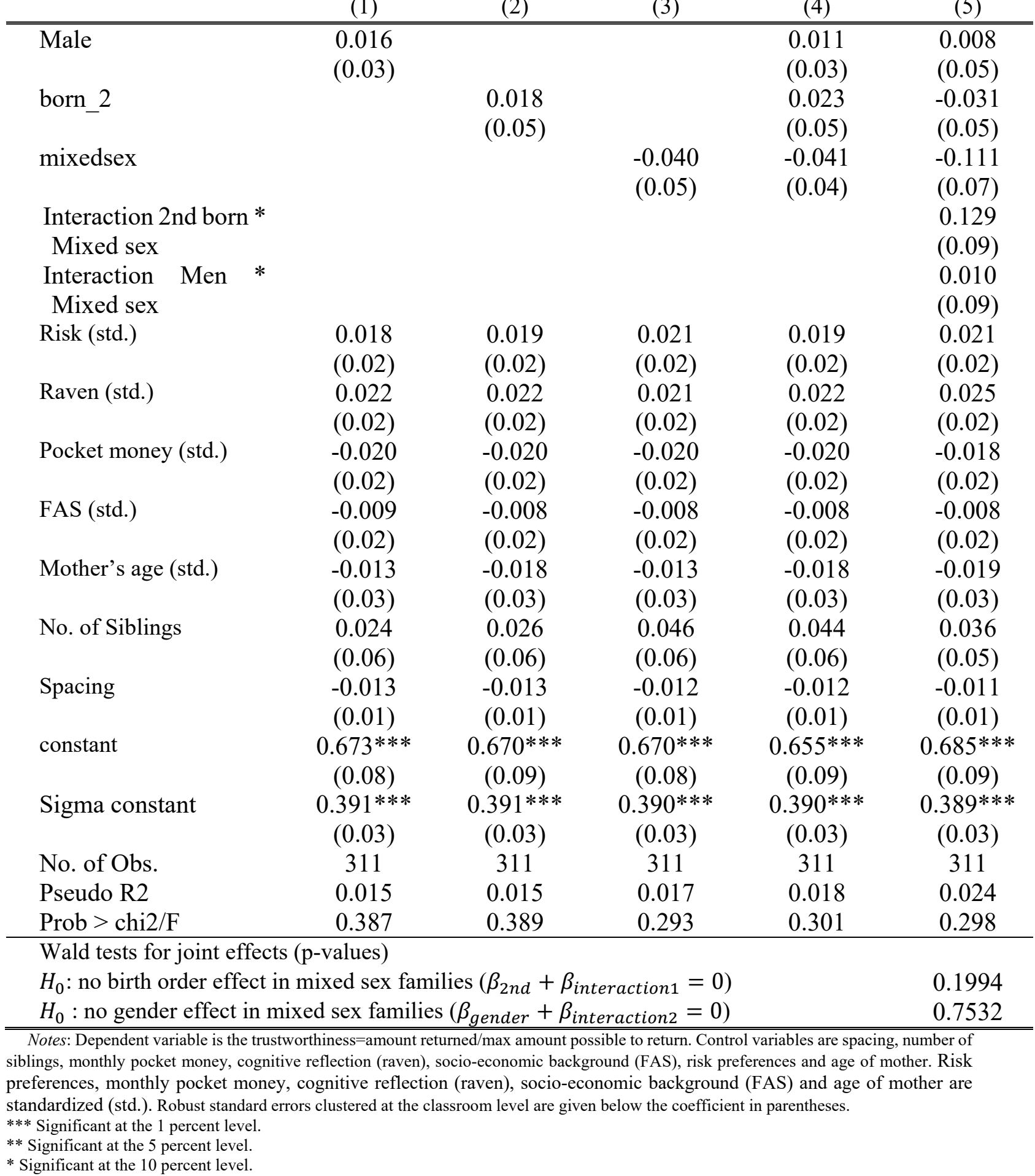

